\title{
CME Information: Cutaneous T-cell lymphoma: 2014 Update on diagnosis, risk-stratification, and management
}

Ryan Wilcox M.D., Ph.D.

CME Editor: Ayalew Tefferi M.D.

If you wish to receive credit for this activity, please refer to the website: www.wileyhealthlearning.com

\section{Accreditation and Designation Statement:}

Blackwell Futura Media Services is accredited by the Accreditation Council for Continuing Medical Education to provide continuing medical education for physicians.

Blackwell Futura Media Services designates this journal-based CME for a maximum of 1 AMA PRA Category 1 Credit ${ }^{T M}$. Physicians should only claim credit commensurate with the extent of their participation in the activity.

\section{Educational Objectives}

Upon completion of this educational activity, participants will be better able to:

1. Appropriately risk-stratify patients with MF/SS

2. Design a treatment plan using a risk-adapted approach.

\section{Activity Disclosures}

No commercial support has been accepted related to the development or publication of this activity.

Author: Ryan Wilcox, M.D., Ph.D. has no conflicts of interest to disclose.

CME Editor: Ayalew Tefferi, M.D. has no conflicts of interest to disclose.

This activity underwent peer review in line with the standards of editorial integrity and publication ethics maintained by American Journal of Hematology. The peer reviewers have no conflicts of interest to disclose. The peer review process for American Journal of Hematology is single blinded. As such, the identities of the reviewers are not disclosed in line with the standard accepted practices of medical journal peer review.

Conflicts of interest have been identified and resolved in accordance with Blackwell Futura Media Services's Policy on Activity Disclosure and Conflict of Interest. The primary resolution method used was peer review and review by a non-conflicted expert.

\section{Instructions on Receiving Credit}

This activity is intended for physicians. For information on applicability and acceptance of continuing medical education credit for this activity, please consult your professional licensing board.

This activity is designed to be completed within one hour; physicians should claim only those credits that reflect the time actually spent in the activity. To successfully earn credit, participants must complete the activity during the valid credit period, which is up to two years from initial publication. Additionally, up to 3 attempts and a score of $70 \%$ or better is needed to pass the post test.

Follow these steps to earn credit:

- Log on to www.wileyhealthlearning.com

- Read the target audience, educational objectives, and activity disclosures.

- Read the activity contents in print or online format.

- Reflect on the activity contents.

- Access the CME Exam, and choose the best answer to each question.

- Complete the required evaluation component of the activity.

- Claim your Certificate.

This activity will be available for CME credit for twelve months following its launch date. At that time, it will be reviewed and potentially updated and extended for an additional twelve months. 


\section{Cutaneous T-cell lymphoma: 2014 Update on diagnosis, risk-stratification, and management}

Ryan A. Wilcox*

Disease overview: Cutaneous T-cell lymphomas are a heterogenous group of T-cell lymphoproliferative disorders involving the skin, the majority of which may be classified as Mycosis Fungoides (MF) or Sézary Syndrome (SS).

Diagnosis: The diagnosis of MF or SS requires the integration of clinical and histopathologic data.

Risk-adapted therapy: TNMB (tumor, node, metastasis, and blood) staging remains the most important prognostic factor in MF/SS and forms the basis for a "risk-adapted," multidisciplinary approach to treatment. For patients with disease limited to the skin, expectant management or skin-directed therapies is preferred, as both disease-specific and overall survival for these patients is favorable. In contrast, patients with advanced-stage disease with significant nodal, visceral or blood involvement are generally approached with biologic-response modifiers or histone deacetylase inhibitors prior to escalating therapy to include systemic, single-agent chemotherapy. Multiagent chemotherapy (e.g., CHOP) may be employed for those patients with extensive visceral involvement requiring rapid disease control. In highly selected patients, allogeneic stemcell transplantation may be considered.

Am. J. Hematol. 89:838-851, 2014. @ 2014 Wiley Periodicals, Inc.

\section{Disease Overview}

Primary cutaneous lymphomas are a heterogenous group of extranodal non-Hodgkin lymphomas, which, by definition, are largely confined to the skin at diagnosis. The European Organization for Research and Treatment of Cancer (EORTC) and World Health Organization (WHO) published a consensus classification for cutaneous lymphomas in 2005 [1]. In contrast to nodal non-Hodgkin lymphoma, most of which are B-cell derived, $\sim 75 \%$ of primary cutaneous lymphomas are T-cell derived, two-thirds of which may be classified as Mycosis fungoides (MF) or Sézary Syndrome (SS) [1-3]. The incidence of cutaneous T-cell lymphomas (CTCL) has been increasing and is currently 6.4 per million persons, based on Surveillance, Epidemiology, and End Results registry data, with the highest incidence rates being reported among males (male:female incidence rate ratio 1.9) and African-Americans (incidence rate ratio 1.5) [2]. While CTCL may occur in children and young adults, this is very uncommon and often associated with histopathologic variants of MF [4-6]. The incidence of CTCL increases significantly with age, with a median age at diagnosis in the mid-50's and a four-fold increase in incidence appreciated in patients over $70[2,6]$.

Epidemiological studies have failed to consistently identify environmental or virally associated risk factors for most CTCL subtypes, with the notable exception of HTLV-1 infection in adult T-cell leukemia/lymphoma [7]. Recent studies, however, have suggested that medications may induce an antigen-driven T-cell lymphoproliferation or dyscrasia [8,9]. A recent case series examined a subset of hypertensive MF/SS patients using hydrochlorothiazide. When compared with hypertensive MF/SS patients not using hydrochlorothiazide, these patients were more likely to have Stage I disease, and were less likely to have a clonal TCR gene rearrangement [9]. More importantly, in a subset of these patients, a complete or partial response was observed upon discontinuation of hydrochlorothiazide. In three patients, CTCL recurred upon reinitiating hydrochlorothiazide, and subsequently receded with its discontinuation. While these findings could be interpreted as a drug reaction, more specifically a drug-induced pseudolymphoma, the authors of this single center study speculate that hydrochlorothiazide may be associated with antigen-driven T-cell lymphoproliferation and could serve as a trigger for MF. Consequently, a therapeutic trial off hydrochlorothiazide may be warranted in selected patients. Moreover, as a variety of other medications may initiate a reaction mimicking MF, a careful medication history should be performed in these patients with a trial off any suspected offending drug. Individual genetic features have also been implicated in the development of CTCL. Rare reports of familial MF and the detection of specific HLA class II alleles in association with both sporadic and familial MF suggest that host genetic factors may contribute to MF development [10-12]. While the role of environmental and host genetic factors in CTCL pathogenesis remains unclear, significant insights into disease ontogeny, molecular pathogenesis, and disease-associated immune dysregulation have been realized.

\section{Cell of origin}

The overwhelming majority of skin-resident $\mathrm{T}$ cells are $\mathrm{CD}_{4} 5 \mathrm{RO}^{+}$memory $\mathrm{T}$ cells expressing the skin-homing addressin CLA, which binds Eselectin on postcapillary venules in the skin and is required for lymphocyte rolling [13]. Skin-resident $\mathrm{T}$ cells highly express the chemokine

Division of Hematology/Oncology, University of Michigan Cancer Center, Ann Arbor, Michigan

Conflict of interest: Nothing to report

${ }^{\star}$ Correspondence to: Ryan Wilcox, MD, PhD, Division of Hematology/Oncology, University of Michigan Cancer Center, 1500 E. Medical Center Drive, Room

4310 CC, Ann Arbor, MI 48109-5948. E-mail: rywilcox@med.umich.edu

Received for publication: 29 April 2014; Accepted: 29 April 2014

Am. J. Hematol. 89:838-851, 2014.

Published online: in Wiley Online Library (wileyonlinelibrary.com).

DOI: $10.1002 /$ ajh.23756 
receptors CCR4, CCR6, and CCR10, among others, that are required for their migration into the skin [13-15]. In contrast to central memory $\mathrm{T}$ cells $\left(T_{\mathrm{CM}}\right)$ expressing CCR7 and L-selectin, that are required for lymph-node homing and circulation in the peripheral blood, effector memory $\mathrm{T}$ cells $\left(T_{\mathrm{EM}}\right)$ form a persistent population of tissueresident cells capable of rapidly responding to antigenic rechallenge and comprise $80 \%$ of $T$ cells residing in normal skin [13]. Immunophenotyping studies demonstrate that malignant $\mathrm{T}$ cells in patients with leukemic CTCL variants (SS) express CCR7 and L-selectin, resembling $T_{\mathrm{CM}}$, while the malignant clone in $\mathrm{MF}$ lesions resembled $T_{\mathrm{EM}}$ [16]. This fundamental difference in the putative cell of origin between SS ( $T_{\mathrm{CM}}$ derived) and MF ( $T_{\mathrm{EM}}$ derived) is consistent with their distinct clinical behavior, as $T_{\mathrm{CM}}$ may be found in both the peripheral blood, lymph node, and skin and are long-lived cells resistant to apoptosis, while skin-resident $T_{\mathrm{EM}}$ cells fail to circulate in peripheral blood, remaining fixed within the skin [16]. The contention that MF and SS originate from different T-cell subsets is consistent with comparative genomic hybridization (CGH) and geneexpression profiling data demonstrating that these CTCL subtypes are genetically distinct $[17,18]$.

Regulatory $\mathrm{T}$ (Treg) cells expressing the transcription factor FoxP3 are important in the maintenance of self-tolerance and form a minor subset of skin-resident $\mathrm{T}$ cells. Heid et al. demonstrated that the malignant $\mathrm{T}$ cells in a subset of Sézary patients may be derived from Treg cells, as the malignant clone in these patients not only expressed FoxP3 and suppressed conventional T cells, but possessed a demethylated FoxP3 promoter [19]. Uncertainties remain as to whether or not a subset of Sézary patients harbor a clone that is derived from bona fide skin resident Treg cells, or whether these cells aberrantly acquire a Treg phenotype during disease evolution [20]. For example, immature dendritic cells, which are prevalent in CTCL [21], may upregulate FoxP3 expression in malignant $\mathrm{T}$ cells [22]. Therefore, a subset of SS patients appears to harbor a Treg-derived (or "Treglike") clone, although the prognostic and therapeutic implications of this observation remain to be defined.

In contrast to Treg cells, which represent a minority of skinresident $\mathrm{T}$ cells, the majority of effector $\mathrm{T}$ cells in the skin are effector $\mathrm{T}$ cells and produce cytokines characteristic of distinct effector T-cell subsets, including Th1, Th2, and Th17 cells. This effector T-cell heterogeneity raises the possibility that future studies may subclassify CTCL based on these T-cell subsets [23]. Of note, MF/SS is associated with the expression of Th2-associated genes (e.g., GATA-3) and the production of Th2-associated cytokines (e.g., IL-4, IL-5, and IL-13), raising the possibility that a significant subset of patients may harbor Th2-derived clones [24-28]. Alternatively, recurrent mutations activating specific signaling pathways (e.g., NFAT, NFKB, and JAK/ STAT) may promote the acquisition of a particular phenotype independent of the cell of origin [29]. T-cell differentiation is associated with considerable plasticity. Therefore, the phenotype of malignant $\mathrm{T}$ cells may be both heterogeneous and highly dependent upon cues within the microenvironment $[22,30]$. As the genetic landscape and the putative cell of origin are further defined in subsets of CTCL, including MF/SS, one may anticipate that this data may have a significant impact on the classification, risk-stratification, and treatment of these diseases.

\section{Immunopathogenesis}

The establishment of long-term CTCL cell lines is challenging, as these cells frequently undergo spontaneous cell death during in vitro culture [31,32] (and personal observation). Therefore, the resistance to apoptosis observed in vivo is unlikely due to an intrinsic resistance to apoptosis alone. Rather, extrinsic factors present within the tumor microenvironment likely contribute to the growth and survival of malignant $\mathrm{T}$ cells, a contention supported by the observation that cytokine supplementation or the provision of T-cell costimulatory signals supports the growth of malignant $\mathrm{T}$ cells in vitro [31,33,34]. Both gene-expression profiling and immunohistochemistry-based studies have recently highlighted the important contribution of nonmalignant cells, including monocyte-derived lymphoma-associated macrophages, in the pathogenesis of both Hodgkin and non-Hodgkin lymphomas [35-37]. Similarly, malignant T cells in the skin are frequently associated with dendritic cells and immunohistochemistrybased studies have clearly demonstrated an abundance of both lymphoma-associated macrophages and dendritic cells, many of which may be actively recruited into the tumor microenvironment by tumor-derived chemokines $[21,38]$. These monocyte-derived cells promote tumorigenesis both directly, by the production of factors, which promote tumor cell growth and survival, and indirectly, by supporting tumor angiogenesis and suppressing host antitumor immunity [39]. For example, monocyte-derived dendritic cells supported the longterm survival of malignant $\mathrm{T}$ cells during in vitro culture [32]. More recently, peripheral blood monocytes (and their progeny) were shown to support the growth of malignant $\mathrm{T}$ cells in vitro, confer resistant to chemotherapy, and promote tumor engraftment in immunodeficient mice [21]. Lymphoma-derived IL-10, which is upregulated in patients with advanced-stage, refractory disease [40], impairs the maturation of lymphoma-associated dendritic cells, rendering them immunologically incompetent, thus promoting escape from host antitumor immune surveillance. In addition, lymphoma-associated dendritic cells were observed to express the T-cell coinhibitory ligand B7H1 (PD-L1 and CD274), which directly inhibits the proliferation of tumor-specific $\mathrm{T}$ cells, and indirectly impairs antitumor immunity by promoting the induction of suppressive Treg cells [41]. Therefore, lymphoma-associated macrophages and dendritic cells appear to play an important role in CTCL while contributing to the evasion and suppression of host antitumor immunity.

In addition to the tumor microenvironment's role, widespread impairment of cellular immunity-the tumor "macroenvironment"has long been appreciated in CTCL and contributes to the significant morbidity and mortality associated with infectious complications observed in CTCL. Approximately 50\% of patients with CTCL, particularly those with advanced-stage disease, will ultimately succumb to infectious complications [42-44]. Both quantitative and qualitative defects in natural killer (NK) cell [45,46], dendritic cell [47], and T cell-mediated [48-50] immunity are observed in CTCL. In addition, CTCL is associated with a significant loss of the T-cell repertoire, analogous to that observed in HIV infection. T-cell receptor (TCR) diversity within multiple TCR beta-variable (V $\beta$ ) families was analyzed using complementarity-determining region 3 (CDR3) spectratyping and combined with a quantitative analysis of TCR-V $\beta$ usage by flow cytometry [51]. In patients with advanced-stage disease, and half of patients with limited-stage disease, a dramatic loss of TCR diversity was observed. Whether this observation may be explained by tumor-mediated suppression of non-malignant $\mathrm{T}$ cells, diminished thymic output of naive $\mathrm{T}$ cells and compensatory homeostatic expansion of oligoclonal peripheral $\mathrm{T}$ cells, or some other mechanism, is unknown [40]. As lymphopenia is an adverse prognostic factor in many hematologic malignancies [52-57], and undoubtedly contributes to the infectious complications observed in CTCL, improved understanding of the causative mechanism(s) leading to this dramatic loss of T-cell diversity may have significant therapeutic implications.

\section{Molecular pathogenesis}

Recurrent chromosomal translocations involving the $\mathrm{IgH}$ gene on chromosome 14 lead to the aberrant expression of antiapoptotic (e.g., $\mathrm{Bcl}-2$ ) and oncogenic (e.g., cyclin D1, Myc) proteins in B-cell 
lymphomas. These recurrent translocations arise in peripheral B cells undergoing class-switch recombination and somatic hypermutation. In contrast, the TCR gene loci, while involved in recurrent chromosomal translocations in precursor T-cell lymphoblastic leukemias/lymphomas, are rarely involved in recurrent translocations in mature $\mathrm{T}$ cell lymphoproliferative disorders [58,59]. With the exception of translocations involving the interferon regulatory factor 4 (IRF4) gene (also known as MUM1) in a subset of cutaneous anaplastic large cell lymphomas, recurrent chromosomal translocations are infrequently observed in CTCL [60-64]. Despite this, a number of signaling pathways regulating cell-cycle progression and survival have been implicated in CTCL pathogenesis.

The NF-kB family of transcription factors (i.e., c-rel, p65/RelA, RelB, p50/p105, and p52/p100) plays an important role in normal lymphocyte development, activation and differentiation via the regulation of target genes involved in cell growth, survival, and cytokine production. Multiple mechanisms, well described in B-cell lymphomas, lead to constitutive NF-kB activation, promoting lymphomagenesis [65]. In a similar fashion, NF-kB is constitutively activated in CTCL [66-68]. Immunohistochemical analysis of MF cases demonstrated nuclear localization of p65/RelA in over $90 \%$ of the cases examined [66]. Furthermore, pharmacologic NF-kB inhibition in CTCL cell lines decreases NF-kB DNA binding activity, thus promoting cell death [66-69]. While the molecular mechanisms leading to constitutive NF-kB activation in CTCL are poorly understood, the observation that IKK inhibition downregulates NF-kB activity implicates upstream IKK-activating elements $[67,68]$.

The signal transducers and activators of transcription (STATs) are a family of six transcription factors which become phosphorylated by one of four upstream receptor-associated Janus kinases (JAKs) following cytokine stimulation. Nuclear localization and DNA-binding of phosphorylated STAT3 has been convincingly demonstrated in CTCL [70,71]. Following nuclear translocation, STAT3 directly regulates a number of target genes in CTCL, including regulators of apoptosis (e.g., Bcl-2/Bax), cytokines (e.g., IL-5 and IL-13), and suppressors of cytokine signaling (e.g., SOCS). In addition, STAT3 indirectly regulates gene expression by inducing the expression of DNA methyltransferase 1 (DNMT1), which promotes the epigenetic silencing of tumor suppressor genes [72]. Not surprisingly then, pharmacologic inhibition of STAT3 promotes apoptosis in CTCL [70,73-75]. Cytogenetic gains involving STAT5A and STAT5B or their activation in response to cytokines present within the tumor microenvironment suggests a pathogenic role for other STATs [76-78].

Normal T cells undergo a controlled process of activation-induced cell death following antigen-dependent activation and proliferation, thus maintaining lymphocyte homeostasis. Extrinsic death receptors, including Fas (CD95), play an important role in regulating this process. A number of mechanisms, including promoter methylation [79-81], gene mutations [82], and loss of the long arm of chromosome 10 [83] result in diminished Fas expression in CTCL and reduced sensitivity to apoptosis. In addition, promoter methylation and epigenetic instability leading to the inactivation of many tumor suppressor genes, including those involved in the induction of apoptosis, appear to be commonly employed mechanisms of lymphomagenesis in CTCL [84].

In addition to multiple defects in apoptosis, aberrant cell-cycle regulation, including inactivation of the CDKN2A-CDKN2B locus, is frequently observed in CTCL $[85,86]$. Cyclin upregulation, including cyclinD1, and loss of RB1 have also been described [87]. As geneexpression profiling and next-generation sequencing technologies are employed, additional pathogenic pathways, including those involving transcription factors regulating T-cell differentiation [27,28], c-MYC [88,89], RAS/RAF/MEK signaling [90], among others [83,91], may be identified in subsets of CTCL. For example, a gain of function mutation $(\mathrm{S} 345 \mathrm{~F})$ in the phospholipase C, gamma 1 (PLCG1) gene was recently observed in 19\% of CTCL cases [29]. This mutation was associated with NFAT activation, and suggests that calcineurin inhibitors may be a rationale therapeutic approach in these patients.

\section{Diagnosis}

\section{Mycosis fungoides}

The definitive diagnosis of MF, particularly patch/plaque stage disease, is challenging, as many of its clinical and pathologic features are nonspecific. Many patients will have had symptoms attributed to eczema or parapsoriasis for years prior to obtaining a definitive diagnosis. The median time from symptom onset to diagnosis in retrospective series is 3-4 years, but may exceed four decades [92-94]. Given the importance of clinicopathological correlation in the diagnosis of MF and the variable association of specific histologic findings with the diagnosis, biopsy reports are not infrequently "suggestive of" the diagnosis. This occasional uncertainty implied in biopsy reports and apparent lack of a more definitive histopathologic diagnosis may be a source of frustration for clinicians unfamiliar with the challenges associated with rendering a pathologic diagnosis of MF. While a definitive diagnosis of MF may be made on the basis of clinical and histopathologic features alone, determination of T-cell clonality and assessment for the aberrant loss of $\mathrm{T}$-cell antigen expression by immunohistochemical staining for $\mathrm{CD} 2, \mathrm{CD} 3, \mathrm{CD} 5$, and $\mathrm{CD} 7$ are useful ancillary studies in the diagnosis of MF (and SS). PCR-based methods are able to detect clonal rearrangements of the TCR in formalin-fixed, paraffin-embedded biopsy specimens [95,96]. PCRbased methods, while sensitive, should be interpreted with caution, as clonal TCR gene rearrangements may be detected in normal elderly individuals and in patients with benign dermatoses or other disease states [97-101]. However, detection of identical clones from two different sites is quite specific for MF [102]. The extent to which MF/SS may be preceded by a premalignant state, analogous to monoclonal B-cell lymphocytosis or monoclonal gammopathy of undetermined significance, is debatable and poorly defined [103]. The malignant lymphocytes in MF/SS are usually $\mathrm{CD} 3^{+} \mathrm{CD} 4^{+}$and $\mathrm{CD} 8^{-}$, but frequently lose the expression of other pan-T-cell antigens. Therefore, demonstration of a significant population of cells lacking CD2, CD5, and/or CD7 expression, either within the entire lesion or the epidermis alone, is highly specific (specificity $>90 \%$ ) for MF in most reported series [104,105]. Clinically, patch/plaque stage MF is frequently characterized by persistent and progressive lesions that develop in a "bathing suit" distribution and vary in size, shape, and color. These lesions are frequently large $(>5 \mathrm{~cm})$, pruritic and multifocal in "classical" MF. However, a broad range of MF variants have been described with differences in tropism (e.g., follicular MF), distribution (e.g., palmoplantar MF), pigmentation (e.g., hypopigmented and hyperpigmented variants) and focality (e.g., unilesional MF), some of which are formally recognized in the WHO-EORTC classification $[1,106]$. Given the need for uniform diagnostic criteria in MF, the International Society for Cutaneous Lymphoma (ISCL) recently proposed a point-based diagnostic algorithm, which integrates clinical, histopathologic, and immunophenotyping data with an assessment of T-cell clonality [107].

\section{Sézary syndrome}

Traditionally, SS is defined as a leukemic form of CTCL associated with erythroderma. A series of studies in the early to mid-20th century, beginning with Sezary's initial landmark observation in 1938, identified a population of large lymphocytes in the peripheral blood with grooved, lobulated (i.e., "cerebriform") nuclei in patients with MF or SS [108-113]. As in other chronic lymphoproliferative disorders, the Sezary cell count is preferably expressed in absolute terms, 
with $>1000$ cells/ $\mu$ l classified as B2 disease in the current ISCL/ EORTC TNMB staging classification. The morphologic detection of Sezary cells in the peripheral blood is not specific for CTCL, as Sezary cells may be found in peripheral blood from normal donors and in benign conditions [114-116]. The histologic findings in the skin often resemble those observed in MF, with less prominent epidermotropism, while lymph node involvement is characterized by complete effacement of the nodal architecture by infiltrating Sezary cells [117].

In SS, clonal $\mathrm{T}$ cells are generally $\mathrm{CD} 3{ }^{+} \mathrm{CD} 4^{+}$and $\mathrm{CD} 8{ }^{-}$by multicolor flow cytometry [118-121]. As in MF, the aberrant loss of panT-cell antigens, including CD2, CD3, CD4, CD5, and CD7 is frequently observed $[120,122,123]$. Of these, the aberrant loss of CD7 expression is most common, being observed in approximately twothirds of cases [122,124,125]. Loss of CD26 expression is also useful in the identification of Sezary cells, being observed in the majority of cases [121,126-128]. More recently, the aberrant expression of the MHC class I-binding, killer immunoglobulin-like receptor CD158 normally expressed by NK cells, was described in the majority of patients examined with SS [129,130]. Molecular studies, including detection of a clonal TCR gene rearrangement by PCR and the presence of a clonal cytogenetic abnormality, provide evidence of T-cell clonality. An alternative approach to demonstrate T-cell clonality incorporates multicolor flow cytometry using a panel of antibodies specific for various TCR beta-chain variable region family members (TCR-V $\beta$ ) [131-133]. This approach is successful in identifying a clonal population of $\mathrm{T}$ cells if this population is significantly higher than the background frequency of polyclonal $\mathrm{T}$ cells harboring the same $\mathrm{V} \beta$ chain [131,132]. Clark et al. recently observed that lymphocytes isolated from either peripheral blood or skin lesions of CTCL patients contained a population of cells with high forward and side scatter characteristics on flow cytometric analysis [134]. A similar population of so-called high-scatter $\mathrm{T}$ cells $\left(T_{\mathrm{HS}}\right)$ was not observed in samples obtained from patients with benign conditions. More importantly, these high-scatter $\mathrm{T}$ cells, upon careful immunophenotyping and analysis of clonal TCR-V $\beta$ chain expression, were convincingly shown to represent the malignant $\mathrm{T}$ cell clone. While additional confirmatory studies are warranted, detection of high-scatter $\mathrm{T}$ cells may be an easily performed method to detect a clonal T-cell population in patients with limited-stage MF and to monitor the response to therapy.

The currently proposed ISCL criteria for SS integrate clinical, histologic, immunophenotyping, and molecular studies. In patients with erythroderma, criteria recommended for the diagnosis of SS by the ISCL include the following: absolute sezary count $\geq 1000 / \mu \mathrm{l}$, a CD4/ $\mathrm{CD} 8$ ratio $\geq 10$ (due to the clonal expansion of $\mathrm{CD} 4^{+}$cells), aberrant expression of pan-T-cell antigens, demonstration of T-cell clonality by Southern blot or PCR-based methods, or cytogenetic demonstration of an abnormal clone [120]. At a minimum, the WHO-EORTC recommends the demonstration of T-cell clonality in combination with the above-mentioned criteria for the diagnosis of SS [1]. In addition to the ISCL criteria, the most recent WHO classification requires erythroderma, generalized lymphadenopathy, and clonally related Tcells (Sézary cells) in the skin, peripheral blood, and lymph nodes. On rare occasions, SS may be preceded by a prior history of classic MF. The ISCL recommends that such cases be designated as "SS preceded by MF." Conversely, patients with MF, but without erythroderma, may meet hematologic criteria for SS. In these cases, the designation "MF with leukemic involvement" is recommended.

\section{Non-MF/SS subtypes of CTCL}

An important goal during a patient's initial diagnostic evaluation is to distinguish non-MF/SS CTCL subtypes from MF/SS, as the natural history, prognosis, and treatment approach for each of the non-MF/ SS lymphomas is highly variable. A detailed description of these
CTCL subtypes is beyond the scope of this update, but the salient features of each have been recently summarized $[1,135]$.

\section{Risk-Stratification}

\section{Staging}

In contrast to many other lymphoproliferative disorders in which cytogenetic and laboratory findings play a prominent role in risk stratification, TNMB (tumor, node, metastasis, and blood) staging remains an important prognostic factor in MF/SS and forms the basis for a "risk-adapted" approach to treatment. In 2007, the ISCL and EORTC revised the TNMB staging of MF/SS [136]. Patients with only patches and plaques have Stage I disease, but may be further divided into Stage IA $(<10 \%$ body surface area involved or T1) or Stage IB ( $>10 \%$ body surface area involved or T2) based on the extent of skin involvement. For practical purposes, the area of one hand (including both palm and digits) represents $\sim 1 \%$ of body surface area. Current staging and diagnostic recommendations do not require a biopsy of clinically normal lymph nodes; however, an excisional biopsy of any abnormal lymph nodes $(\geq 1.5 \mathrm{~cm}$ in diameter or firm/fixed) is recommended, with preference being given either to the largest lymph node draining an area of skin involvement or to the node with the greatest standardized uptake value on FDG-PET imaging. In current practice, two pathologic staging systems are used to classify the extent of nodal involvement. In the Dutch system, lymph nodes are pathologically graded based on the presence of large cerebriform nuclei $(>7.5 \mu \mathrm{m})$ and the degree of architectural effacement [137]. In contrast, the NCI-VA classification uses the relative number of atypical lymphocytes (not size), along with nodal architecture to determine the extent of nodal involvement $[138,139]$. Patients with patch/plaque stage disease (T1/T2) and architectural preservation of any clinically abnormal lymph nodes are classified as Stage IIA. Collectively, patients with Stage I and IIA disease have "limited-stage" disease, as the overall survival in these patients is measured in decades, with survival in patients with Stage IA disease resembling that of normal age-matched controls [6,92,93]. At diagnosis, the majority of MF patients will have limited-stage disease [6]. In contrast, patients with tumor stage disease (T3), erythroderma (T4), nodal involvement characterized by partial or complete architectural effacement (N3), visceral metastases (M1), or significant leukemic involvement (B2) have "advanced-stage" disease. Detection of a clonal TCR gene rearrangement by PCR, which has been incorporated into the revised ISCL/EORTC node $(\mathrm{N})$ and blood (B) staging classification, is an adverse prognostic factor [6,140-143]. Unfortunately, median survivals from $\sim 1-5$ years are observed in these patients with more extensive disease [6]. The revised ISCL/EORTC staging for MF/SS is summarized in Table I.

A recently reported retrospective study, which included 1,398 MF patients, $71 \%$ with patch/plaque stage disease and 104 SS patients has validated the revised ISCL/EORTC staging classification [6]. On univariate and multivariate analyses, the revised $\mathrm{T}, \mathrm{N}, \mathrm{M}$, and B classification were significantly associated with overall and disease-specific survival. The median survival, disease-specific survival and risk of disease progression, by clinical stage, are summarized in Table I. In addition to staging, male gender, increasing age, an elevated $\mathrm{LDH}$ and the folliculotropic variant of MF were also independently associated with poorer overall and disease-specific survival. In contrast to previous reports highlighting the aggressive clinical course associated with large cell transformation [144-148], defined as the presence of large, atypical lymphocytes comprising at least $25 \%$ of the total lymphoid infiltrate, large cell transformation was not an independent predictor of overall or disease-specific survival, but was associated with a higher risk (hazard ratio $=3.32$ ) of disease progression [6]. Given the importance of the TNMB classification in risk stratification 
TABLE I. ISCL/EORTC Staging

\begin{tabular}{|c|c|c|c|c|c|c|c|c|}
\hline \multirow[b]{2}{*}{ Stage } & \multicolumn{4}{|c|}{ TNMB classification } & \multirow[b]{2}{*}{ Median OS (years) } & \multicolumn{3}{|c|}{ 10-Year(6) } \\
\hline & $T$ & $N$ & $M$ & $B$ & & OS (\%) & DSS (\%) & RDP (\%) \\
\hline IA & 1 & 0 & 0 & 0,1 & 35.5 & 88 & 95 & 12 \\
\hline IB & 2 & 0 & 0 & 0,1 & 21.5 & 70 & 77 & 38 \\
\hline$\| \mathrm{A}$ & 1,2 & 1 & 0 & 0,1 & 15.8 & 52 & 67 & 33 \\
\hline IIB & 3 & $0-2$ & 0 & 0,1 & 4.7 & 34 & 42 & 58 \\
\hline IIIA & 4 & $0-2$ & 0 & 0 & 4.7 & 37 & 45 & 62 \\
\hline IIIB & 4 & $0-2$ & 0 & 1 & 3.4 & 25 & 45 & 73 \\
\hline IVA1 & $1-4$ & $0-2$ & 0 & 2 & 3.8 & 18 & 20 & 83 \\
\hline IVA2 & $1-4$ & 3 & 0 & $0-2$ & 2.1 & 15 & 20 & 80 \\
\hline IVB & $1-4$ & $0-3$ & 1 & $0-2$ & 1.4 & 18 (5 year) & 18 (5 year) & 82 (5 year) \\
\hline
\end{tabular}

DSS: disease-specific survival; OS: overall survival; RDP: risk of disease progression.

and defining disease burden, the ISCL/EORTC recommends its use in defining the initial, maximum, and current burden of disease, which will ultimately play an important role in the selection of either skindirected or systemic therapies [136].

Recognizing that the staging system used for MF/SS is less helpful for non-MF/SS cutaneous lymphomas, a new TNM classification was also proposed for these CTCL variants [149]. Due to the significant heterogeneity of these lymphomas, this staging system does not provide prognostic information, but is intended to provide a uniform description of the disease burden.

\section{Cytogenetics}

In contrast to some B-cell lymphoproliferative disorders, like chronic lymphocytic leukemia and multiple myeloma, for which gene-expression profiling and cytogenetic findings have important prognostic implications, risk-stratification in CTCL based on cytogenetic findings has only recently been described, is poorly understood, and consequently is not routinely performed in clinical practice.

Shin et al. performed a gene expression profiling analysis on lesional skin biopsy specimens obtained from 62 CTCL patients and identified three distinct gene expression clusters that were prognostically important [40], that were later confirmed by RT-PCR analysis [150]. The first cluster was associated with the upregulation of genes involved in T-cell activation, homing and tumor necrosis factor signaling. This cluster conferred an inferior event-free survival when compared with the other two clusters. The second cluster, associated with the upregulation of genes involved in keratinocyte and epidermal proliferation and differentiation, was comprised largely of patients with limited-stage disease and was, not surprisingly, associated with superior event-free survival. Cluster 3, associated with an event-free survival intermediate between the first two clusters, was associated with the upregulation of genes involved in keratinocyte function and WNT signaling.

Array-CGH techniques have revealed chromosomal copy number alterations that are prognostically relevant. First, an inverse association between survival and the absolute number of copy number alterations, reflecting genomic instability, has been observed in both tumor-stage MF and SS [151,152]. For example, in a cohort of 28 SS patients, the presence of fewer than 3 copy number alterations was associated with a median overall-survival of 93 months, compared with a median overall-survival of 67 months for those with 3 or more copy number alterations [151]. In addition to genomic complexity, specific chromosomal gains/losses have also been associated with inferior survival. Unfortunately, many of these studies are small and hindered by the inclusion of multiple histologies. For example, in a cohort of 58 patients with transformed MF, SS, or cutaneous anaplastic large cell lymphoma (cALCL), loss of the CDKN2A-CDKN2B locus (at 9p21) was associated with inferior overall survival that was highly significant. However, 9p21 loss was only found in a single patient with cALCL. Therefore, when these patients were omitted from analysis, the loss of 9p21 was associated with decreased overall survival that approached, but did not reach, statistical significance [86]. Despite this, the adverse prognostic significance of 9 p21 loss is supported by multiple patient cohorts including both MF and SS $[17,18,152]$. Additional cytogenetic abnormalities, involving gains of chromosomes $1 \mathrm{q}$ and $8 \mathrm{q}$ and losses of chromosome 10q, have been associated with inferior survival [135].

\section{Treatment of Limited-Stage MF}

As the majority of CTCL patients present with patch/plaque stage MF and have an excellent prognosis, the initial goal of therapy is to improve symptoms and quality of life while avoiding treatmentrelated toxicity. For many patients, this may involve either expectant management (i.e., "watch and wait") or skin-directed therapies. A randomized trial comparing early combined modality therapy, including both radiation and multiagent chemotherapy (cyclophosphamide, doxorubicin, etoposide, and vincristine), with sequential topical therapies demonstrated that combined-modality therapy, while associated with a superior complete response rate, did not translate into improvements in disease-free or overall survival and was associated with significant toxicity [153]. Therefore, patients with limited-stage disease who require therapy are best approached with skin-directed therapies, usually under the direction of a dermatologist and/or radiation oncologist. Excellent reviews and treatment guidelines are available $[135,154-159]$.

\section{Treatment of Advanced-Stage MF/SS}

\section{Overview}

Patients with advanced-stage MF/SS require a multidisciplinary approach, as various combinations of skin-directed therapies, biologic-response modifiers, and ultimately the sequential use of systemic chemotherapeutic agents are frequently employed in the management of these patients. As for limited-stage disease, multiagent chemotherapy, with only few exceptions, is generally not appropriate [153]. As summarized in Fig. 1, a "risk-adapted" stage-based approach is adopted, with biologic-response modifiers (e.g., bexarotene and interferon-alpha) and histone deacetylase (HDACs) inhibitors (e.g., vorinostat) generally preferred prior to escalating therapy to include systemic chemotherapy. Therapeutic decisions are individualized and based on a patient's age, performance status, extent of disease burden, the rate of disease progression, and previous therapies. The concise treatment algorithm provided in Fig. 1 is consistent with published treatment guidelines and expert opinion [154-159]. 


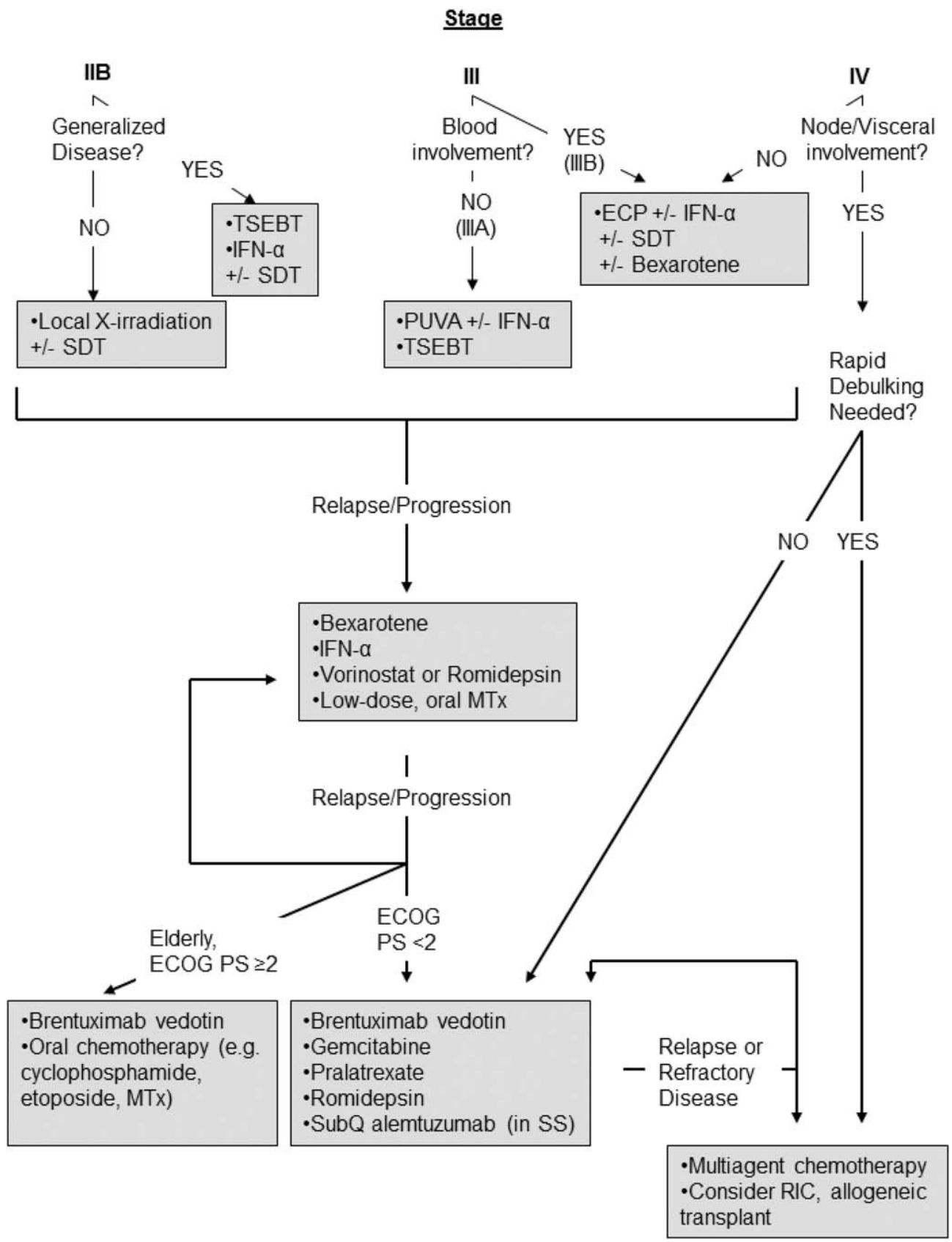

Figure 1. Approach to treatment of advanced-stage MF/SS. Abbreviations: MTx: methotrexate; RIC: reduced-intensity conditioning; SDT: skindirected therapy; TSEBT: total skin electron beam therapy. Clinical trial participation, whenever possible, is encouraged.

\section{Bexarotene}

The endogenous retinoids all-trans retinoic acid and 9-cis retinoic acid (i.e., vitamin-A-derived compounds) regulate a diverse array of biologic processes, ranging from embryonic development to cell growth, differentiation and survival, upon binding two families of steroid hormone receptors, the retinoic acid receptors (RAR) and retinoid X receptors (RXR). Upon forming homodimers or heterodimers, these receptors recruit various nuclear corepressor or coactivator proteins depending whether or not they are bound by ligand. Multiple RAR retinoids have been used in MF/SS, either topically or systemically (reviewed in $[160,161]$ ), with response rates exceeding 50\%. However, in 1999 the oral RXR-selective "rexinoid" bexarotene was FDA approved for CTCL and was later approved as a topical gel formulation. Laboratory studies demonstrate that bexarotene promotes cell cycle arrest and apoptosis in CTCL cell lines [162,163]. In a multicenter phase II-III study, 94 patients with advanced-stage CTCL who had been previously treated with a median of five prior therapies, the vast majority of whom had disease refractory to at least one prior systemic therapy, received at least $300 \mathrm{mg} / \mathrm{m}^{2}$ of oral bexarotene daily [164]. Among patients treated at the $300 \mathrm{mg} / \mathrm{m}^{2}$ dose, an overall response rate of $45 \%$ was observed, only $2 \%$ of which were complete. While an improved overall response rate was noted with the use of higher doses, this difference was not statistically significant, and doselimiting toxicity was far more common (50 vs. $89 \%$ ) in these patients. While a dose-response relationship is likely, the $300 \mathrm{mg} / \mathrm{m}^{2}$ dose appears to provide the optimal risk-benefit ratio. The most common toxicities associated with therapy were hypertriglyceridemia (in 82\%) and central hypothyroidism (29\%). Myelosuppression is infrequent and usually uncomplicated. Pancreatitis secondary to hypertriglyceridemia may be rarely observed, but is reversible upon discontinuation of treatment. Therefore, a baseline lipid panel and TSH should be obtained prior to the initiation of therapy. In one retrospective study, 
all patients treated with bexarotene developed hyperlipidemia and hypothyroidism, frequently within weeks of initiating treatment [165]. Consequently, use of lipid-lowering agents (e.g., fenofibrate) and lowdose levothyroxine (e.g., $50 \mu \mathrm{g}$ ) prior to initiating bexarotene is generally recommended [166-168]. In clinical practice, bexarotene is frequently initiated at a lower dose of $150 \mathrm{mg} / \mathrm{m}^{2}$ and subsequently titrated to full doses after 4 weeks of therapy, depending upon patient tolerability. Most responses occur within 2-3 months of treatment initiation, but may be delayed. Therefore, in the absence of disease progression or toxicity, treatment should be continued for up to 6 months. For responding patients, treatment should be continued until disease progression and, depending upon the quality of the response, adjunctive skin-directed therapies (e.g., PUVA, interferon) should be considered [169]. Guidelines describing appropriate laboratory monitoring, supportive care, and safe clinical prescribing of bexarotene have been recently published [168]. Future studies clarifying the optimal use of bexarotene, either in combination or sequentially with other agents, are needed.

\section{HDAC inhibitors}

HDACs catalyze the removal of acetyl groups from both histone and nonhistone proteins. As histone acetylation is associated with an open chromatin configuration associated with active gene transcription, HDACs contribute to histone deacetylation and the epigenetic repression of gene transcription. As HDACs regulate a wide variety of processes involved in carcinogenesis, multiple mechanisms may explain the clinical activity of HDAC inhibitors [170,171], including altered gene expression of cell-cycle and apoptotic regulatory proteins [172-176], acetylation of nonhistone proteins regulating cell growth and survival [177-180], angiogenesis [181,182], aggresome formation [183], and DNA repair [184]. In addition, HDAC inhibitors may have important effects on the tumor microenvironment via reactive oxygen species [185,186], enhanced antigen presentation [187], and downregulation of immunomodulatory cytokines, like IL-10 [188].

Vorinostat (suberoylanilide hydroxamic acid, SAHA) and romidepsin (depsipeptide) inhibit class I and II HDACs (i.e., pan-HDAC inhibitors), the former being widely expressed in various lymphoma subtypes [189]. Early phase I studies of both vorinostat and romidepsin established their safety and potential efficacy in lymphoproliferative disorders, including CTCL [190], thus paving the way for larger phase II studies. An earlier phase II study established $400 \mathrm{mg}$ of oral vorinostat once daily as the optimal dose that was investigated further in 74 previously treated patients with CTCL, most of whom $(>80 \%)$ had advanced-stage disease [191,192]. The overall response rate was $\sim 30 \%$ for patients with advanced-stage disease and was associated with a median duration of response estimated to exceed 185 days. Most responses were rapid (i.e., $<2$ months) and were also noted in patients with tumor-stage disease and Sézary syndrome [193]. Patients who failed to achieve an objective response appeared to derive some clinical benefit, including stable disease, decreased lymphadenopathy and pruritis relief, with treatment. The most common non-hematologic adverse events, observed in almost $50 \%$ of patients, were gastrointestinal toxicities (nausea, vomiting, and diarrhea). Hematologic toxicities, including anemia or thrombocytopenia, were observed in up to $20 \%$ of patients. Among responding patients, long-term therapy with vorinostat appears to be well tolerated [194]. Prolongation of the QT interval was rarely observed, but monitoring and appropriate electrolyte replacement is recommended for those patients at risk for QT prolongation.

Romidepsin, administered as a 4-hr intravenous infusion (14 mg/ $\mathrm{m}^{2}$ ) days 1,8 , and 15 every 4 weeks, was evaluated in two phase II studies, the largest of which included 96 patients, most with advanced-stage disease [195,196]. The overall response rate was 38\% for patients with advanced-stage disease, with a median duration of response that exceeded one year. A toxicity profile similar to that described for vorinostat was observed. Intensive cardiac monitoring in a subset of these patients failed to demonstrate any clinically significant cardiotoxicity [197].

Additional HDAC inhibitors, including potent pan-HDAC inhibitors, appear to have activity in CTCL [176,198,199]. Further studies are needed to fully define the mechanisms of resistance to HDAC inhibition in CTCL [176,200-204], enabling the development of rational therapeutic combinations incorporating HDAC inhibitors in CTCL $[205,206]$.

\section{Interferon-alpha}

Interferon-alpha (i.e., interferon-alpha 2b), a Type I interferon with immunomodulatory properties, has pleiotropic effects in CTCL and is associated with an overall response rate of $50-70 \%$ and a complete response rate of $20-30 \%$, particularly in patients with limitedstage disease [207-210]. While often considered as second-line therapy for limited-stage CTCL, interferon-alpha, frequently at doses ranging from 3 to 10 million units daily to three times weekly, is a treatment to be considered in the first-line setting in patients with advanced-stage disease. Responses, which may be achieved within a few months, are observed in patients with tumor-stage MF and SS. Furthermore, interferon-alpha may be successfully combined with a number of other therapeutic modalities frequently used in the management of these patients, including PUVA, bexarotene, chemotherapy, and ECP [211-224]. For example, in a cohort of 51, mostly advanced-stage patients treated with single-agent, low-dose, interferon-alpha, responses were observed in 34 (67\%), including 21 (41\%) with a complete response and 9 with a long-term remission [210]. Similarly, in a cohort of 47 patients with Stages III/IV disease, $89 \%$ of whom had peripheral blood involvement, a response rate exceeding $80 \%$ was observed in those treated with a combination of ECP and interferon-alpha [224]. Interferon-alpha is associated with myelosuppression, transaminitis, and dose-limiting flu-like side effects, particularly at higher doses.

\section{Extracorporeal photophoresis (ECP)}

During ECP pooled leukapheresis and plasmapheresis products are exposed to 8-methoxypsoralen (8-MOP) prior to extracorporeal circulation through a $1 \mathrm{~mm}$ thick disposable cassette exposed to UVA radiation. The irradiated leukocytes, representing $\sim 5 \%$ of peripheral blood leukocytes, are subsequently reinfused. Psoralen covalently binds and crosslinks DNA following UVA exposure, leading to the induction of apoptosis in the majority of treated lymphocytes by multiple mechanisms involving bcl-2 family members, disruption of the mitochondrial membrane potential and extrinsic cell death pathways [225-227]. In contrast, ECP leads to monocyte activation, including significant changes in gene expression [228], and dendritic cell differentiation, which is thought to culminate in enhanced antigen presentation and the initiation of a host immune response [229]. In hopes of prolonging the exposure time between monocyte-derived dendritic cells and malignant lymphocytes undergoing apoptosis, investigators have developed a modified ECP protocol (i.e., "transimmunization") whereby blood products are incubated overnight following UVA irradiation and prior to patient infusion [230]. This novel adaptation is investigational and has not been widely employed given concerns about infectious risks and lack of a proven increase in efficacy.

Following the landmark study by Edelson et al. describing responses in 27 out of 37 patients with erythrodermic CTCL treated with ECP, ECP was approved by the Food and Drug Administration of the USA for the treatment of CTCL and is now considered the treatment of choice in the first-line management of patients with Sézary syndrome in many centers [231]. While responses vary between case series, overall response rates hover around $60 \%$, with a 
complete response rate of $\sim 20 \%$ [232-235]. As current treatment protocols no longer require the oral administration of 8-MOP, eliminating nausea, ECP is safe and generally very well tolerated. While alternative schedules have been investigated, ECP is generally performed for 2 consecutive days every 2-4 weeks. While the precise mechanism of action is incompletely understood, evidence suggests that ECP has immunomodulatory effects, which may augment host antitumor immunity. It is not surprising then that the median time to response following the initiation of ECP is $\sim 6$ months. Median survival exceeding 8 years has been observed in ECP treated patients and among complete responders, many experience durable responses, which may permit, for some, weaning from CTCL-directed therapies [232,236-238]. While patient- or disease-specific factors which may predict a response to therapy are imperfect, patients for whom treatment is initiated promptly after diagnosis who have circulating Sézary cells, but without significant nodal or visceral disease, may be more likely to respond. In addition, patients without profound immune deficiencies, reflected by normal or near-normal cytotoxic T-cell and CD4/CD8 values and the absence of prior exposure to systemic chemotherapy, may be more likely to respond to therapy [232,234,237]. While effective as monotherapy, ECP has also been combined with other therapeutic strategies, including interferon, bexarotene, and TSEBT [214,224,236,239-241].

\section{Monoclonal antibodies}

In contrast to many B-cell lymphoproliferative disorders, where the incorporation of CD20-targeting monoclonal antibodies has become the standard of care, additional studies are needed to identify the optimal approach targeting T-cell specific antigens in advancedstage MF/SS. Alemtuzumab is a humanized IgG1 monoclonal antibody directed against CD52, an antigen widely expressed by B-cells, T-cells, and monocytes [242]. In a phase II study in 22 patients with advanced-stage MF/SS, overall and complete response rates of 55 and $32 \%$, respectively, were observed, with a median time to treatment failure of 1 year [243]. Given the significant risk of infectious complications, low-dose subcutaneous alemtuzumab was investigated in 14 patients with SS, most of whom had relapsed/refractory disease [244]. Most patients in this study received $3 \mathrm{mg}$ of subcutaneous alemtuzumab on day 1 followed by a $10 \mathrm{mg}$ dose on alternating days until the Sézary count was $<1000 \mathrm{~mm}^{3}$. With the exception of a single patient whose best response was stable disease, 9 out of 10 patients treated in this manner achieved a response, 3 of which were complete. For most patients, the time to treatment failure exceeded 12 months. What is notable, however, is that infectious complications were not observed in patients treated with the lowest dose (i.e., $10 \mathrm{mg}$ ) of alemtuzumab. Similar results, with no infectious complications, were recently reported in a small cohort of patients treated with modified, lowdose, subcutaneous alemtuzumab for six weeks [245]. In addition to hematologic toxicity, conventionally dosed alemtuzumab in advancedstage MF/SS is associated with a high incidence of infectious complications [243,244,246-249]. Overall, infectious complications have been observed in two-thirds of treated patients, most of which are bacterial, including sepsis. Cytomegalovirus (CMV) reactivation is the most common viral infection. In addition, Pneumocystis jirovecii pneumonia and invasive fungal infections have also been observed. Therefore, trimethoprim-sulphamethoxazole and acyclovir should be routinely administered for PJP and HSV/VZV prophylaxis, respectively, in patients receiving alemtuzumab. In addition, CMV surveillance should be performed every 1-2 weeks by quantitative PCR and suppressive therapy with ganciclovir or oral valganciclovir initiated in response to viral reactivation. Low-dose, subcutaneous alemtuzumab appears to be safe and efficacious in selected patients with advancedstage MF/SS provided with appropriate supportive care. Monoclonal antibodies targeting additional T-cell specific antigens, including CD2
[250], CD4 [251], CD25 [252], and CCR4 [253-255] are being explored and appear promising. Mogamulizumab (KW-0761) is a humanized monoclonal antibody specific for the chemokine receptor CCR4 that has been defucosylated and is consequently associated with enhanced antibody-dependent cell-mediated cytotoxicity. In a phase I/2 study, mogamulizumab was well tolerated and was associated with an overall response rate of $37 \%$. A similar response rate of $29 \%(2 / 7)$, all partial, was observed in a phase II Japanese study [255,256]. A randomized, phase III clinical trial comparing mogamulizumab and vorinostat in relapsed/refractory CTCL is ongoing in the US (NCT01728805). Brentuximab vedotin is an antibody-drug conjugate in which an anti-CD30 monoclonal antibody is linked with an anti-tubulin agent (monomethyl auristatin E). In a phase II study, 19 patients with relapsed/refractory MF received brentuximab vedotin. Among the 13 patients with Stages IB or IIB disease, a response rate of $92 \%$ (all partial) was observed [257]. As a single partial response was observed among the 6 patients with Stage IV disease, an overall response rate of $68 \%$ for the entire cohort was observed. Interestingly, quantitative image analysis for CD30 expression demonstrated CD30 positivity in all cases available for review, including those that were deemed CD30 negative by conventional immunohistochemistry. The response to brentuximab vedotin was not associated with CD30 expression in this cohort. As anticipated, neuropathy was the most common toxicity observed. A randomized, phase III clinical trial comparing brentuximab vedotin with an investigator's choice (methotrexate or bexarotene) is ongoing (NCT01578499).

\section{Systemic chemotherapy}

Systemic chemotherapy is generally reserved for patients with advanced-stage MF/SS who have either relapsed following therapy with skin-directed therapies and the biologic-response modifiers described above or have extensive disease with visceral organ involvement. Multiple chemotherapeutic agents, including single-agent and combination chemotherapy regimens, are associated with high response rates in MF/SS and have been reviewed recently $[155,157,258]$. While combination chemotherapy regimens (e.g., $\mathrm{CHOP}$ ) are associated with response rates exceeding $70-80 \%$, the responses achieved are frequently short-lived and are associated with significant myelosuppression and infectious complications [259-261]. Therefore, with the exceptions of refractory disease or in the setting of extensive or rapidly progressive disease where a rapid treatment response may be necessary, the administration of sequential, singleagent chemotherapy, as summarized in Fig. 1, is preferred.

Low-doses of oral chemotherapy, including methotrexate (as used for limited-stage CTCL), cyclophosphamide, chlorambucil, or etoposide, may be considered for patients with minimal disease burden that is slowly progressive or for elderly patients with a poor performance status. For example, overall response rates of $58-76 \%$ (and $41 \%$ complete response rate) have been observed in patients with MF/SS treated with low-dose, oral methotrexate [262-265]. In contrast, for patients with an adequate performance status, single-agent gemcitabine [266-270], pegylated liposomal doxorubicin [271-274], and pentostatin [275-281] have been used. Gemcitabine, a pyrimidine nucleoside analog, is associated with overall and complete response rates of $50-70 \%$ and $10-20 \%$, respectively, but is associated with neutropenia and nonhematologic toxicities [282]. Zinzani et al. recently reported long-term outcomes in a cohort of previously treated T-cell lymphoma patients [270]. Among the $19 \mathrm{MF}$ patients included in the study, an overall and complete response rate of 48 and $16 \%$, respectively, was observed. Overall, 7 out of 9 complete responders remained in continuous complete remission with a disease-free interval ranging from 15 months to 10 years. In the largest prospective study of pegylated liposomal doxorubicin, an overall response rate of $56 \%$, with a complete response rate of $20 \%$, was reported [274]. Pegylated 
liposomal doxorubicin is generally well tolerated, with a lower incidence of neutropenia than gemcitabine, but with occasional infusionrelated and mucocutaneous toxicities, including palmoplantar erythrodysesthesia. The most durable responses with pentostatin, a purine antimetabolite, which inhibits adenosine deaminase, have been reported in SS [281]. Pentostatin is associated with fewer complete responses $(\sim 10-20 \%)$ and significant lymphopenia-associated immunosuppression. Unfortunately, the duration of response with these agents is frequently measured in months. Therefore, novel therapeutic agents, either alone or in combination, are needed.

Pralatrexate, a novel antifolate with a high affinity for the reduced folate carrier (RFC-1) and novel mechanism of resistance when compared with methotrexate [283-285], was associated with an overall response rate of $29 \%$ in the PROPEL study. This study was comprised largely of peripheral T-cell lymphoma patients, most of whom had refractory disease [286]. Notably, twelve patients with transformed MF were included in the study [287]. Many of these patients had received more than 5 prior systemic therapies, including CHOP or CHOP-like regimens. With only a single exception, these patients were refractory to their most recent therapy. Responses, as assessed by the study investigators, were observed in $58 \%$ of patients with a median duration of response and progression-free survival of 4-5 months. Results of a dose-finding study were reported in a larger cohort of CTCL patients [288]. In this study, the optimal dose was identified as $15 \mathrm{mg} / \mathrm{m}^{2}$, given weekly 3 weeks out of 4 , and was associated with an overall response rate of $43 \%$. In an effort to reduce the incidence of mucositis, folic acid and vitamin B12 supplementation is routinely provided in these patients [289]. Additional agents, including bortezomib [290], are being explored. As there is no standard of care for patients with MF/SS requiring systemic chemotherapy and the decision to initiate therapy is individualized, including consideration of responses and complications related to prior therapies, participation in a well-designed clinical trial is always worth consideration.

\section{High-dose chemotherapy and hematopoietic stem cell transplantation}

The available experience with high-dose chemotherapy and autologous stem cell transplantation, largely confined to case series, suggests that responses following treatment are frequently transient. In contrast, the durable remissions observed following allogeneic transplantation may be explained by the graft versus lymphoma immune response [291,292]. A retrospective analysis of 60 patients with advanced-stage MF/SS who underwent allogeneic stem cell transplan- tation was recently reported [293]. In this series, patients had received a median of 4 prior therapies prior to undergoing either reducedconditioning $(73 \%)$ or myeloablative $(27 \%)$ conditioning prior to related $(75 \%)$ or matched-unrelated donor (25\%) transplantation. Nonrelapse mortality at 1 year was $14 \%$ for patients receiving reduced-intensity conditioning or HLA identical/related donor stem cells and $38-40 \%$ for those undergoing myeloablative conditioning or receiving match-unrelated donor grafts. Transplantation during an early phase of disease (defined as first or second remission or relapse following 3 or fewer systemic therapies) was associated with lower relapse rates (25 vs. $44 \%$ at 1 year) and a statistically insignificant increase in 3-year overall survival (68 vs. $46 \%$ ). Given the differences in non-relapse mortality, both reduced-intensity conditioning and use of matched-related donors were associated with superior overall survival (63\% at 3 years). Seventeen out of 26 patients who relapsed received donor-lymphocyte infusions. Of these, $47 \%$ achieved a complete remission, thus providing evidence for a graft-versus-lymphoma effect in MF/SS. In contrast to the experience with B-cell non-Hodgkin lymphomas, chemotherapy sensitivity prior to transplantation or the extent of disease burden did not influence overall survival. The estimated 3-year progression-free and overall survival were 34 and $53 \%$, respectively. Given the possibility of complete and durable remissions, allogeneic stem-cell transplantation may be considered in highly selected patients [294].

\section{Summary}

Establishing a definitive diagnosis of CTCL, accurate disease staging and risk-stratification, and the selection of appropriate therapy requires a multidisciplinary approach. While high response rates may be achieved with systemic chemotherapy, these responses are frequently short-lived and associated with significant toxicities. As treatment of advanced-stage MF/SS is largely palliative, a stage-based approach using sequential therapies in an escalated fashion is preferred. Participation in a well-designed clinical trial is encouraged, as the introduction of novel agents will continue to expand the therapeutic options available in the management of CTCL.

\section{Acknowledgments}

The authors would like to thank Mark Kaminski and Alexandra C. Hristov for their thoughtful review of this manuscript and helpful discussions.

\section{References}

1. Willemze R, Jaffe ES, Burg G, et al. WHOEORTC classification for cutaneous lymphomas. Blood 2005; 105:3768-3785.

2. Criscione VD, Weinstock MA. Incidence of cutaneous T-cell lymphoma in the United States, 1973-2002. Arch Dermatol 2007;143: 854-859.

3. Bradford PT, Devesa SS, Anderson WF, Toro JR. Cutaneous lymphoma incidence patterns in the United States: A population-based study of 3884 cases. Blood 2009;113:5064-5073.

4. Burns MK, Ellis CN, Cooper KD. Mycosis fungoides-type cutaneous T-cell lymphoma arising before 30 years of age. Immunophenotypic, immunogenotypic and clinicopathologic analysis of nine cases. J Am Acad Dermatol 1992;27: 974-978.

5. Pope E, Weitzman S, Ngan B, et al. Mycosis fungoides in the pediatric population: Report from an international childhood registry of cutaneous lymphoma. J Cutan Med Surg 2010; $14: 1-6$

6. Agar NS, Wedgeworth E, Crichton S, et al. Survival outcomes and prognostic factors in mycosis fungoides/Sezary syndrome: Validation of the revised International Society for Cutaneous Lymphomas/European Organisation for Research and Treatment of Cancer staging proposal. J Clin Oncol 2010;28:4730-4739.

7. Whittemore AS, Holly EA, Lee IM, et al. Mycosis fungoides in relation to environmental exposures and immune response: A case-control study. J Natl Cancer Inst 1989;81:1560-1567.

8. Magro CM, Crowson AN, Kovatich AJ, Burns F. Drug-induced reversible lymphoid dyscrasia: A clonal lymphomatoid dermatitis of memory and activated T cells. Hum Pathol 2003;34:119129 .

9. Jahan-Tigh RR, Huen AO, Lee GL, et al. Hydrochlorothiazide and cutaneous $\mathrm{T}$ cell lymphoma: Prospective analysis and case series. Cancer 2013;119:825-831.

10. Hodak E, Klein T, Gabay B, et al. Familial mycosis fungoides: Report of 6 kindreds and a study of the HLA system. J Am Acad Dermatol 2005;52:393-402.

11. Hodak E, Lapidoth M, Kohn K, et al. Mycosis fungoides: HLA class II associations among Ashkenazi and non-Ashkenazi Jewish patients. Br J Dermatol 2001;145:974-980.

12. Jackow CM, McHam JB, Friss A, et al. HLADR5 and DQB1 ${ }^{*} 03$ class II alleles are associated with cutaneous T-cell lymphoma. J Invest Dermatol 1996;107:373-376.

13. Clark RA, Chong B, Mirchandani N, et al. The vast majority of CLA $+\mathrm{T}$ cells are resident in normal skin. J Immunol 2006;176:4431-4439.

14. Reiss Y, Proudfoot AE, Power CA, et al. CC chemokine receptor (CCR)4 and the CCR10 ligand cutaneous $\mathrm{T}$ cell-attracting chemokine (CTACK) in lymphocyte trafficking to inflamed skin. J Exp Med 2001;194:1541-1547.

15. Homey B, Alenius H, Muller A, et al. CCL27CCR10 interactions regulate $\mathrm{T}$ cell-mediated skin inflammation. Nat Med 2002;8:157-165.

16. Campbell JJ, Clark RA, Watanabe R, Kupper TS. Sezary syndrome and mycosis fungoides arise from distinct $\mathrm{T}$-cell subsets: A biologic rationale for their distinct clinical behaviors. Blood 2010;116:767-771.

17. Laharanne E, Oumouhou N, Bonnet F, et al. Genome-wide analysis of cutaneous T-cell lymphomas identifies three clinically relevant classes. J Invest Dermatol 2010;130:17071718.

18. van Doorn R, van Kester MS, Dijkman R, et al Oncogenomic analysis of mycosis fungoides reveals major differences with Sezary syndrome. Blood 2009;113:127-136. 
19. Heid JB, Schmidt A, Oberle N, et al. FOXP3+CD25- tumor cells with regulatory function in Sezary syndrome. J Invest Dermatol 2009;129:2875-2885.

20. Krejsgaard T, Odum N, Geisler C, et al. Regulatory $\mathrm{T}$ cells and immunodeficiency in mycosis fungoides and Sezary syndrome. Leukemia 2012; 26:424-432.

21. Wilcox RA, Wada DA, Ziesmer SC, et al. Monocytes promote tumor cell survival in T-cell lymphoproliferative disorders and are impaired in their ability to differentiate into mature dendritic cells. Blood 2009;114:2936-2944.

22. Berger CL, Tigelaar R, Cohen J, et al. Cutaneous T-cell lymphoma: Malignant proliferation of Tregulatory cells. Blood 2005;105:1640-1647.

23. Clark RA. Skin-resident T cells: The ups and downs of on site immunity. J Invest Dermatol 2010;130:362-370.

24. Vowels BR, Lessin SR, Cassin M, et al. Th2 cytokine mRNA expression in skin in cutaneous T-cell lymphoma. J Invest Dermatol 1994;103: 669-673.

25. Vowels BR, Cassin M, Vonderheid EC, Rook AH. Aberrant cytokine production by Sezary syndrome patients: Cytokine secretion pattern resembles murine Th2 cells. J Invest Dermatol 1992;99:90-94.

26. Suchin KR, Cassin M, Gottleib SL, et al. Increased interleukin 5 production in eosinophilic Sezary syndrome: Regulation by interferon alfa and interleukin 12. J Am Acad Dermatol 2001;44:28-32.

27. Kari L, Loboda A, Nebozhyn M, et al. Classification and prediction of survival in patients with the leukemic phase of cutaneous $\mathrm{T}$ cell lymphoma. J Exp Med 2003;197:1477-1488.

28. Nebozhyn M, Loboda A, Kari L, et al. Quantitative PCR on 5 genes reliably identifies CTCL patients with $5 \%$ to $99 \%$ circulating tumor cells with 90\% accuracy. Blood 2006;107:3189-3196.

29. Vaque JP, Gomez-Lopez G, Monsalvez V, et al. PLCG1 mutations in cutaneous T-cell lymphomas. Blood 2014;123:2034-2043.

30. Kasprzycka M, Zhang Q, Witkiewicz A, et al. Gamma c-signaling cytokines induce a regulatory $\mathrm{T}$ cell phenotype in malignant $\mathrm{CD} 4+\mathrm{T}$ lymphocytes. J Immunol 2008;181:2506-2512.

31. Dalloul A, Laroche L, Bagot M, et al. Interleukin-7 is a growth factor for Sezary lymphoma cells. J Clin Invest 1992;90:1054-1060.

32. Berger CL, Hanlon D, Kanada D, et al. The growth of cutaneous T-cell lymphoma is stimulated by immature dendritic cells. Blood 2002; 99:2929-2939.

33. Yamanaka K, Clark R, Rich B, et al. Skin derived interleukin-7 contributes to the proliferation of lymphocytes in cutaneous T-cell lymphoma. Blood 2006;107:2440-2445.

34. McCusker ME, Garifallou M, Bogen SA. Sezary lineage cells can be induced to proliferate via CD28-mediated costimulation. J Immunol 1997; 158:4984-4991.

35. Dave SS, Wright G, Tan B, et al. Prediction of survival in follicular lymphoma based on moleclar features of tumor-infiltrating immune cells. N Engl J Med 2004;351:2159-2169.

36. Rosenwald A, Wright G, Chan WC, et al. The use of molecular profiling to predict survival after chemotherapy for diffuse large-B-cell lymphoma. N Engl J Med 2002;346:1937-1947.

37. Steidl C, Lee T, Shah SP, et al. Tumor-associated macrophages and survival in classic Hodgkin's lymphoma. N Engl J Med 2010;362:875-885.

38. Schlapbach C, Ochsenbein A, Kaelin U, et al. High numbers of DC-SIGN+ dendritic cells in lesional skin of cutaneous T-cell lymphoma. J Am Acad Dermatol 2010;62:995-1004.

39. Wilcox RA. Cancer-associated myeloproliferation: Old association, new therapeutic target. Mayo Clin Proc 2010;85:656-663.

40. Shin J, Monti S, Aires DJ, et al. Lesional gene expression profiling in cutaneous T-cell lymphoma reveals natural clusters associated with disease outcome. Blood 2007;110:3015-3027.

41. Wilcox RA, Feldman AL, Wada DA, et al. B7H1 (PD-L1, CD274) suppresses host immunity in T-cell lymphoproliferative disorders. Blood 2009;114:2149-2158.

42. Epstein EH Jr., Levin DL, Croft JD Jr., Lutzner MA. Mycosis fungoides. Survival, prognostic features, response to therapy, and autopsy findings. Medicine (Baltimore) 1972;51:61-72.

43. Posner LE, Fossieck BE Jr., Eddy JL, Bunn PA Ir. Septicemic complications of the cutaneous Tcell lymphomas. Am J Med 1981;71:210-216.

44. Axelrod PI, Lorber B, Vonderheid EC. Infections complicating mycosis fungoides and Sezary syndrome. JAMA 1992;267:1354-1358.

45. Wysocka M, Benoit BM, Newton S, et al. Enhancement of the host immune responses in cutaneous T-cell lymphoma by CpG oligodeoxynucleotides and IL-15. Blood 2004;104:41424149

46. Bouaziz JD, Ortonne N, Giustiniani J, et al. Circulating natural killer lymphocytes are potential cytotoxic effectors against autologous malignan cells in sezary syndrome patients. J Invest Dermatol 2005;125:1273-1278.

47. Wysocka M, Zaki MH, French LE, et al. Sezary syndrome patients demonstrate a defect in dendritic cell populations: Effects of CD40 ligand and treatment with GM-CSF on dendritic cell numbers and the production of cytokines. Blood 2002;100:3287-3294.

48. French LE, Huard B, Wysocka $M$, et al Impaired CD40L signaling is a cause of defective IL-12 and TNF-alpha production in Sezary syndrome: Circumvention by hexameric soluble CD40L. Blood 2005;105:219-225.

49. Samimi S, Benoit B, Evans K, et al. Increased programmed death-1 expression on $\mathrm{CD} 4+\mathrm{T}$ cells in cutaneous T-cell lymphoma: Implications for immune suppression. Arch Dermatol 2010;146:1382-1388.

50. Lee BN, Duvic M, Tang CK, et al. Dysregulated synthesis of intracellular type 1 and type 2 cytokines by $\mathrm{T}$ cells of patients with cutaneous $\mathrm{T}$ cell lymphoma. Clin Diagn Lab Immunol 1999; 6:79-84.

51. Yawalkar N, Ferenczi K, Jones DA, et al. Profound loss of T-cell receptor repertoire complex ity in cutaneous T-cell lymphoma. Blood 2003; 102:4059-4066.

52. Behl D, Ristow K, Markovic SN, et al. Absolute lymphocyte count predicts therapeutic efficacy of rituximab therapy in follicular lymphomas. Br J Haematol 2007;137:409-415.

53. Porrata LF, Gertz MA, Inwards DJ, et al. Early lymphocyte recovery predicts superior survival after autologous hematopoietic stem cell transplantation in multiple myeloma or nonHodgkin lymphoma. Blood 2001;98:579-585

54. Porrata LF, Inwards DJ, Ansell SM, et al. Early lymphocyte recovery predicts superior survival after autologous stem cell transplantation in non-Hodgkin lymphoma: A prospective study. Biol Blood Marrow Transplant 2008;14:807816.

55. Porrata LF, Ristow K, Habermann TM, et al Absolute lymphocyte count at the time of firs relapse predicts survival in patients with diffuse arge B-cell lymphoma. Am J Hematol 2009;84. 93-97.

56. Porrata LF, Rsitow K, Inwards DJ, et al. Lymphopenia assessed during routine follow-up after mmunochemotherapy (R-CHOP) is a risk factor for predicting relapse in patients with diffuse large B-cell lymphoma. Leukemia 2010;24:13431349.

57. Siddiqui M, Ristow K, Markovic SN, et al. Absolute lymphocyte count predicts overall surviva in follicular lymphomas. Br J Haematol 2006; 134:596-601.

58. Leich E, Haralambieva E, Zettl A, et al. Tissue microarray-based screening for chromosomal breakpoints affecting the T-cell receptor gene loci in mature T-cell lymphomas. J Pathol 2007; 213:99-105.

59. Feldman AL, Law M, Grogg KL, et al. Incidence of TCR and TCL1 gene translocations and isochromosome $7 \mathrm{q}$ in peripheral $\mathrm{T}$-cell lymphomas using fluorescence in situ hybridization. Am J Clin Pathol 2008;130:178-185.
60. Pham-Ledard A, Prochazkova-Carlotti M Laharanne E, et al. IRF4 gene rearrangements define a subgroup of CD30-positive cutaneous T-cell lymphoma: A study of 54 cases. J Invest Dermatol 2010;130:816-825.

61. Feldman AL, Law M, Remstein ED, et al. Recurrent translocations involving the IRF4 oncogene locus in peripheral T-cell lymphomas. Leukemia 2009;23:574-580.

62. Wada DA, Law ME, Hsi ED, et al. Specificity of IRF4 translocations for primary cutaneous anaplastic large cell lymphoma: A multicenter study of 204 skin biopsies. Mod Pathol 2010;24:596605 .

63. Batista DA, Vonderheid EC, Hawkins A, et al. Multicolor fluorescence in situ hybridization (SKY) in mycosis fungoides and Sezary syndrome: Search for recurrent chromosome abnormalities. Genes Chromosomes Cancer 2006;45: 383-391.

64. Thangavelu M, Finn WG, Yelavarthi KK, et al. Recurring structural chromosome abnormalities in peripheral blood lymphocytes of patients with mycosis fungoides/Sezary syndrome. Blood 1997;89:3371-3377.

65. Staudt LM. Oncogenic activation of NF-kappaB Cold Spring Harb Perspect Biol 2010;2:a000109.

66. Izban KF, Ergin M, Qin JZ, et al. Constitutive expression of NF-kappa B is a characteristic feature of mycosis fungoides: Implications for apoptosis resistance and pathogenesis. Hum Pathol 2000;31:1482-1490.

67. Sors A, Jean-Louis F, Pellet C, et al. Down-regulating constitutive activation of the NF-kappaB canonical pathway overcomes the resistance of cutaneous T-cell lymphoma to apoptosis. Blood 2006;107:2354-2363.

68. Sors A, Jean-Louis F, Begue E, et al. Inhibition of IkappaB kinase subunit 2 in cutaneous T-cell lymphoma down-regulates nuclear factorkappaB constitutive activation, induces cell death, and potentiates the apoptotic response to antineoplastic chemotherapeutic agents. Clin Cancer Res 2008;14:901-911.

69. Juvekar A, Manna S, Ramaswami S, et al. Bortezomib induces nuclear translocation of IkappaBalpha resulting in gene-specific suppression of NF-kappaB-dependent transcription and induction of apoptosis in CTCL. Mol Cancer Res 2011;9:183-194.

70. Nielsen M, Kaltoft K, Nordahl M, et al. Constitutive activation of a slowly migrating isoform of Stat3 in mycosis fungoides: Tyrphostin AG490 inhibits Stat3 activation and growth of mycosis fungoides tumor cell lines. Proc Nat Acad Sci USA 1997;94:6764-6769.

71. Sommer VH, Clemmensen OJ, Nielsen O, et al In vivo activation of STAT3 in cutaneous T-cell lymphoma. Evidence for an antiapoptotic function of STAT3. Leukemia 2004;18:1288-1295.

72. Zhang Q, Wang HY, Woetmann A, et al. STAT3 induces transcription of the DNA methyltransferase 1 gene (DNMT1) in malignant $\mathrm{T}$ lymphocytes. Blood 2006;108:1058-1064

73. Verma NK, Davies AM, Long A, et al. STAT3 knockdown by siRNA induces apoptosis in human cutaneous T-cell lymphoma line Hut78 via downregulation of Bcl-xL. Cell Mol Biol Lett 2010;15:342-355.

74. Zhang C, Li B, Zhang X, et al. Curcumin selectively induces apoptosis in cutaneous T-cell lymphoma cell lines and patients' PBMCs: Potential role for STAT-3 and NF-kappaB signaling. J Invest Dermatol 2010;130:2110-2119.

75. Nielsen M, Kaestel CG, Eriksen KW, et al. Inhibition of constitutively activated Stat 3 correlates with altered $\mathrm{Bcl}-2 / \mathrm{Bax}$ expression and induction of apoptosis in mycosis fungoides tumor cells. Leukemia 1999;13:735-738.

76. Marzec M, Halasa K, Kasprzycka M, et al. Differential effects of interleukin-2 and interleukin-15 versus interleukin- 21 on CD4+ cutaneous T-cell lymphoma cells. Cancer Res 2008;68:1083-1091.

77. Mao X, Lillington DM, Czepulkowski B, et al Molecular cytogenetic characterization of Sezary syndrome. Genes Chromosomes Cancer 2003; $36: 250-260$ 
78. Barba G, Matteucci C, Girolomoni G, et al. Comparative genomic hybridization identifies $17 q 11.2$ approximately q12 duplication as an early event in cutaneous T-cell lymphomas. Cancer Genet Cytogenet 2008;184:48-51.

79. Wu J, Nihal M, Siddiqui J, et al. Low FAS/CD95 expression by CTCL correlates with reduced sensitivity to apoptosis that can be restored by FAS upregulation. I Invest Dermatol 2009;129: $1165-1173$.

80. Wu J, Wood GS. Reduction of Fas/CD95 promoter methylation, upregulation of Fas protein and enhancement of sensitivity to apoptosis in cutaneous T-Cell lymphoma. Arch Dermatol 2011;147:443-449.

81. Jones CL, Wain EM, Chu CC, et al. Downregulation of Fas gene expression in Sezary syndrome is associated with promoter hypermethylation. J Invest Dermatol 2010;130: $1116-1125$

82. Dereure O, Levi E, Vonderheid EC, Kadin ME. Infrequent Fas mutations but no Bax or p53 mutations in early mycosis fungoides: A possible mechanism for the accumulation of malignant $T$ lymphocytes in the skin. J Invest Dermatol 2002;118:949-956.

83. Scarisbrick JJ, Woolford AJ, Russell-Jones R, Whittaker SJ. Loss of heterozygosity on $10 \mathrm{q}$ and microsatellite instability in advanced stages of primary cutaneous T-cell lymphoma and possible association with homozygous deletion of PTEN. Blood 2000:95:2937-2942.

84. van Doorn R, Zoutman WH, Dijkman R, et al. Epigenetic profiling of cutaneous T-cell lymphoma: Promoter hypermethylation of multiple tumor suppressor genes including BCL7a PTPRG, and p73. J Clin Oncol 2005;23:38863896.

85. Scarisbrick JJ, Woolford AJ, Calonje E, et al Frequent abnormalities of the p15 and p16 genes in mycosis fungoides and sezary syndrome. J Invest Dermatol 2002;118:493-499.

86. Laharanne $\mathrm{E}$, Chevret $\mathrm{E}$, Idrissi $\mathrm{Y}$, et al. CDKN2A-CDKN2B deletion defines an aggressive subset of cutaneous T-cell lymphoma. Mod Pathol 2010;23:547-558.

87. Mao X, Orchard G, Vonderheid EC, et al. Heterogeneous abnormalities of CCND1 and RB1 in primary cutaneous T-Cell lymphomas suggesting impaired cell cycle control in disease pathogenesis. J Invest Dermatol 2006;126:13881395.

88. Kennah E, Ringrose A, Zhou LL, et al. Identification of tyrosine kinase, HCK, and tumor suppressor, BIN1, as potential mediators of AHI-1 oncogene in primary and transformed CTCL cells. Blood 2009;113:4646-4655.

89. Qin JZ, Dummer R, Burg G, Dobbeling U. Constitutive and interleukin-7/interleukin-15 stimulated DNA binding of Myc, Jun, and nove Myc-like proteins in cutaneous T-cell lymphoma cells. Blood 1999;93:260-267.

90. Kiessling MK, Oberholzer PA, Mondal C, et al. High-throughput mutation profiling of CTCL samples reveals KRAS and NRAS mutations sensitizing tumors toward inhibition of the RAS/RAF/MEK signaling cascade. Blood 2011; 117:2433-2440

91. Krejsgaard T, Vetter-Kauczok CS, Woetmann A et al. Ectopic expression of B-lymphoid kinase in cutaneous T-cell lymphoma. Blood 2009;113. 5896-5904

92. Kim YH, Liu HL, Mraz-Gernhard S, et al. Longterm outcome of 525 patients with mycosis fungoides and Sezary syndrome: Clinical prognostic factors and risk for disease progression. Arch Dermatol 2003;139:857-866.

93. van Doorn R, Van Haselen CW, van Voorst Vader PC, et al. Mycosis fungoides: Disease evolution and prognosis of 309 Dutch patients. Arch Dermatol 2000;136:504-510.

94. Arulogun SO, Prince HM, Ng J, et al. Longterm outcomes of patients with advanced-stage cutaneous T-cell lymphoma and large cell transformation. Blood 2008;112:3082-3087.

95. Morgan SM, Hodges E, Mitchell TJ, et al. Molecular analysis of T-cell receptor beta genes in cutaneous T-cell lymphoma reveals Jbeta1 bias. J Invest Dermatol 2006;126:1893-1899.

96. Ponti R, Quaglino P, Novelli M, et al. T-cell receptor gamma gene rearrangement by multiplex polymerase chain reaction/heteroduplex analysis in patients with cutaneous T-cell lymphoma (mycosis fungoides/Sezary syndrome) and benign inflammatory disease: Correlation with clinical, histological and immunophenotypical findings. Br J Dermatol 2005;153:565-573.

97. Guitart J, Magro C. Cutaneous T-cell lymphoid dyscrasia: A unifying term for idiopathic chronic dermatoses with persistent T-cell clones. Arch Dermatol 2007;143:921-932.

98. Posnett DN, Sinha R, Kabak S, Russo C. Clonal populations of $\mathrm{T}$ cells in normal elderly humans: The T cell equivalent to "benign monoclonal gammapathy". J Exp Med 1994;179:609618.

99. Epling-Burnette PK, Painter JS, Rollison DE et al. Prevalence and clinical association of clonal T-cell expansions in Myelodysplastic Syndrome. Leukemia 2007;21:659-667.

100. Martinez A, Pittaluga S, Villamor N, et al Clonal T-cell populations and increased risk for cytotoxic T-cell lymphomas in B-CLI patients: Clinicopathologic observations and molecular analysis. Am J Surg Pathol 2004;28: 849-858.

101. Kohler S, Jones CD, Warnke RA, Zehnder JL. PCR-heteroduplex analysis of $\mathrm{T}$-cell receptor gamma gene rearrangement in paraffinembedded skin biopsies. Am J Dermatopathol 2000;22:321-327.

02. Thurber SE, Zhang B, Kim YH, et al. T-cell clonality analysis in biopsy specimens from two different skin sites shows high specificity in the diagnosis of patients with suggested mycosis fungoides. J Am Acad Dermatol 2007; 57:782-790.

103. Gniadecki R, Lukowsky A. Monoclonal T-cell dyscrasia of undetermined significance associated with recalcitrant erythroderma. Arch Dermatol 2005;141:361-367.

104. Ormsby A, Bergfeld WF, Tubbs RR, Hsi ED. Evaluation of a new paraffin-reactive CD7 Tcell deletion marker and a polymerase chain reaction-based $\mathrm{T}$-cell receptor gene rearrangement assay: Implications for diagnosis of mycosis fungoides in community clinical practice. J Am Acad Dermatol 2001;45:405-413.

105. Michie SA, Abel EA, Hoppe RT, et al. Discordant expression of antigens between intraepider mal and intradermal $\mathrm{T}$ cells in mycosis fungoides. Am J Pathol 1990;137:1447-1451.

106. Kazakov DV, Burg G, Kempf W. Clinicopathological spectrum of mycosis fungoides. J Eur Acad Dermatol Venereol 2004;18:397-415.

107. Pimpinelli N, Olsen EA, Santucci M, et al Defining early mycosis fungoides. J Am Acad Dermatol 2005;53:1053-1063.

108. Sezary A, Bouvrain Y. Erythrodermie avec presence de cellules monstrueses dans le derme et le sang circulant. Bull Soc Fr Derm Syph 1938;45:254-260.

109. Main RA, Goodall HB, Swanson WC. Sezary's syndrome. Br J Dermatol 1959;71:335-343.

110. Taswell HF, Winkelmann RK. Sezary syndrome-a malignant reticulemic erythroderma. JAMA 1961:177:465-472.

111. Lutzner MA, Emerit I, Durepaire R, et al Cytogenetic, cytophotometric, and ultrastructural study of large cerebriform cells of the Sezary syndrome and description of a smallcell variant. J Natl Cancer Inst 1973;50:11451162.

112. Lutzner MA, Jordan HW. The ultrastructure of an abnormal cell in Sezary's syndrome. Blood 1968;31:719-726

113. Edelson RL, Lutzner MA, Kirkpatrick $\mathrm{CH}$ et al. Morphologic and functional properties of the atypical $\mathrm{T}$ lymphocytes of the Sezary syndrome. Mayo Clin Proc 1974;49:558-566.

114. Lutzner MA, Hobbs JW, Horvath P. Ultrastructure of abnormal cells in Sezary syndrome, mycosis fungoides, and parapsoriasis en plaque. Arch Dermatol 1971;103:375-386.
115. Matutes E, Robinson D, O'Brien M, et al. Candidate counterparts of Sezary cells and adult Tcell lymphoma-leukaemia cells in normal peripheral blood: An ultrastructural study with the immunogold method and monoclonal antibodies. Leuk Res 1983;7:787-801.

116. Reinhold U, Herpertz M, Kukel S, et al. Induction of nuclear contour irregularity during $\mathrm{T}$ cell activation via the $\mathrm{T}$-cell receptor/CD3 complex and CD2 antigens in the presence of phorbol esters. Blood 1994;83:703-706.

117. Scheffer E, Meijer CJ, van Vloten WA, Willemze R. A histologic study of lymph nodes from patients with the Sezary syndrome. Cancer 1986;57:2375-2380.

118. Willemze R, van Vloten WA, Hermans J, et al Diagnostic criteria in Sezary's syndrome: A multiparameter study of peripheral blood lymphocytes in 32 patients with erythroderma. J Invest Dermatol 1983;81:392-397.

119. Boumsell L, Bernard A, Reinherz EL, et al. Surface antigens on malignant Sezary and T-CLL cells correspond to those of mature $\mathrm{T}$ cells. Blood 1981;57:526-530.

120. Vonderheid EC, Bernengo MG, Burg G, et al. Update on erythrodermic cutaneous T-cell lymphoma: Report of the International Society for Cutaneous Lymphomas. J Am Acad Dermatol 2002;46:95-106.

121. Hristov AC, Vonderheid EC, Borowitz MJ Simplified flow cytometric assessment in mycosis fungoides and Sezary syndrome. Am J Clin Pathol 2011;136:944-953.

122. Bernengo MG, Quaglino P, Novelli M, et al. Prognostic factors in Sezary syndrome: A multivariate analysis of clinical, haematological and immunological features. Ann Oncol 1998;9: 857-863.

123. Harmon CB, Witzig TE, Katzmann JA Pittelkow MR. Detection of circulating T cells with CD4+CD7- immunophenotype in patients with benign and malignant lymphoproliferative dermatoses. J Am Acad Dermatol 1996;35:404-410.

124. Bogen SA, Pelley D, Charif M, et al. Immunophenotypic identification of Sezary cells in peripheral blood. Am J Clin Pathol 1996;106: 739-748

125. Ginaldi L, Matutes E, Farahat N, et al. Differential expression of CD3 and CD7 in T-cell malignancies: A quantitative study by flow cytometry. Br J Haematol 1996;93:921-927.

126. Jones D, Dang NH, Duvic M, et al. Absence of CD26 expression is a useful marker for diagnosis of T-cell lymphoma in peripheral blood. Am J Clin Pathol 2001;115:885-892.

127. Pierson DM, Jones D, Muzzafar T, et al. Utility of CD26 in flow cytometric immunophenotyping of T-cell lymphomas in tissue and body fluid specimens. Cytometry B Clin Cytom 2008;74:341-348

128. Sokolowska-Wojdylo M, Wenzel J, Gaffal E, et al. Absence of CD26 expression on skinhoming CLA $+\mathrm{CD} 4+\mathrm{T}$ lymphocytes in peripheral blood is a highly sensitive marker for early diagnosis and therapeutic monitoring of patients with Sezary syndrome. Clin Exp Dermatol 2005;30:702-706.

129. Bahler DW, Hartung L, Hill S, et al. CD158k KIR3DL2 is a useful marker for identifying neoplastic T-cells in Sezary syndrome by flow cytometry. Cytometry B Clin Cytom 2008;74: $156-162$

130. Poszepczynska-Guigne E, Schiavon V, D'Incan $\mathrm{M}$, et al. CD158k/KIR3DL2 is a new phenotypic marker of Sezary cells: Relevance for the diagnosis and follow-up of Sezary syndrome. J Invest Dermatol 2004;122:820-823.

131. Klemke CD, Brade J, Weckesser S, et al. The diagnosis of Sezary syndrome on peripheral blood by flow cytometry requires the use of multiple markers. Br J Dermatol 2008;159:871880

132. Morice WG, Kimlinger T, Katzmann JA, et al Flow cytometric assessment of TCR-Vbeta expression in the evaluation of peripheral blood involvement by $\mathrm{T}$-cell lymphoprolifera- 
tive disorders: A comparison with conventional T-cell immunophenotyping and molecular genetic techniques. Am J Clin Pathol 2004;121: 373-383.

133. Schwab C, Willers J, Niederer E, et al. The use of anti-T-cell receptor-Vbeta antibodies for the estimation of treatment success and phenotypic characterization of clonal T-cell populations in cutaneous T-cell lymphomas. Br J Haematol 2002;118:1019-1026.

134. Clark RA, Shackelton JB, Watanabe R, et al. High-scatter T cells: A reliable biomarker for malignant $\mathrm{T}$ cells in cutaneous T-cell lymphoma. Blood 2011;117:1966-1976.

135. Wilcox RA. Cutaneous T-cell lymphoma: 2011 update on diagnosis, risk-stratification, and management. Am J Hematol 2011;86:928-948.

136. Olsen E, Vonderheid E, Pimpinelli N, et al. Revisions to the staging and classification of mycosis fungoides and Sezary syndrome: A proposal of the International Society for Cutaneous Lymphomas (ISCL) and the cutaneous lymphoma task force of the European Organization of Research and Treatment of Cancer (EORTC). Blood 2007;110:1713-1722.

137. Scheffer E, Meijer CJ, Van Vloten WA. Dermatopathic lymphadenopathy and lymph node involvement in mycosis fungoides. Cancer 1980;45:137-148.

138. Sausville EA, Worsham GF, Matthews MJ, et al. Histologic assessment of lymph nodes in mycosis fungoides/Sezary syndrome (cutaneous T-cell lymphoma): Clinical correlations and prognostic import of a new classification system. Hum Pathol 1985;16:1098-1109.

139. Clendenning WE, Rappaport HW. Report of the Committee on pathology of cutaneous $\mathrm{T}$ cell lymphomas. Cancer Treat Rep 1979;63: 719-724.

140. Fraser-Andrews EA, Mitchell T, Ferreira S, et al. Molecular staging of lymph nodes from 60 patients with mycosis fungoides and Sezary syndrome: Correlation with histopathology and outcome suggests prognostic relevance in mycosis fungoides. $\mathrm{Br}$ J Dermatol 2006;155: 756-762.

141. Assaf C, Hummel M, Steinhoff M, et al. Early TCR-beta and TCR-gamma PCR detection of $\mathrm{T}$-cell clonality indicates minimal tumor disease in lymph nodes of cutaneous T-cell lymphoma: Diagnostic and prognostic implications. Blood 2005;105:503-510.

142. Scarisbrick JJ, Whittaker S, Evans AV, et al. Prognostic significance of tumor burden in the blood of patients with erythrodermic primary cutaneous T-cell lymphoma. Blood 2001;97: 624-630.

143. Fraser-Andrews EA, Woolford AJ, RussellJones R, et al. Detection of a peripheral blood $\mathrm{T}$ cell clone is an independent prognostic marker in mycosis fungoides. J Invest Dermatol 2000;114:117-121.

144. Vergier B, de Muret A, Beylot-Barry M, et al. Transformation of mycosis fungoides: Clinicopathological and prognostic features of 45 cases. French Study Group of Cutaneious Lymphomas. Blood 2000;95:2212-2218.

145. Greer JP, Salhany KE, Cousar JB, et al. Clinical features associated with transformation of cerebriform T-cell lymphoma to a large cell process. Hematol Oncol 1990;8:215-227.

146. Salhany KE, Cousar JB, Greer JP, et al. Transformation of cutaneous $\mathrm{T}$ cell lymphoma to large cell lymphoma. A clinicopathologic and immunologic study. Am J Pathol 1988;132: 265-277.

147. Diamandidou E, Colome M, Fayad L, et al. Prognostic factor analysis in mycosis fungoides/Sezary syndrome. J Am Acad Dermatol 1999;40:914-924.

148. Diamandidou E, Colome-Grimmer M, Fayad $\mathrm{L}$, et al. Transformation of mycosis fungoides/ Sezary syndrome: Clinical characteristics and prognosis. Blood 1998;92:1150-1159.

149. Kim YH, Willemze R, Pimpinelli $\mathrm{N}$, et al. TNM classification system for primary cutaneous lymphomas other than mycosis fungoides and Sezary syndrome: A proposal of the International Society for Cutaneous Lymphomas (ISCL) and the Cutaneous Lymphoma Task Force of the European Organization of Research and Treatment of Cancer (EORTC). Blood 2007;110:479-484.

150. Litvinov IV, Jones DA, Sasseville D, Kupper TS. Transcriptional profiles predict disease outcome in patients with cutaneous T-cell lymphoma. Clin Cancer Res 2010;16:21062114.

151. Caprini E, Cristofoletti C, Arcelli D, et al Identification of key regions and genes important in the pathogenesis of sezary syndrome by combining genomic and expression microar rays. Cancer Res 2009;69:8438-8446.

152. Salgado R, Servitje O, Gallardo F, et al. Oligonucleotide array-CGH identifies genomic subgroups and prognostic markers for tumor stage mycosis fungoides. J Invest Dermatol 2010;130: 1126-1135.

153. Kaye FJ, Bunn PA Jr., Steinberg SM, et al. A randomized trial comparing combination electron-beam radiation and chemotherapy with topical therapy in the initial treatment of mycosis fungoides. N Engl J Med 1989;321: 1784-1790.

154. Trautinger F, Knobler R, Willemze $\mathrm{R}$, et al EORTC consensus recommendations for the treatment of mycosis fungoides/Sezary syndrome. Eur J Cancer 2006;42:1014-1030.

155. Lansigan F, Foss FM. Current and emerging treatment strategies for cutaneous T-cell lymphoma. Drugs 2010;70:273-286.

156. Horwitz SM, Olsen EA, Duvic M, et al. Review of the treatment of mycosis fungoides and sezary syndrome: A stage-based approach. J Natl Compr Canc Netw 2008;6:436-442.

157. Prince HM, Whittaker S, Hoppe RT. How I treat mycosis fungoides and Sezary syndrome. Blood 2009;114:4337-4353.

158. Whittaker SJ, Marsden JR, Spittle M, et al. Joint British Association of Dermatologists and U.K. Cutaneous Lymphoma Group guidelines for the management of primary cutaneous $\mathrm{T}$ cell lymphomas. Br J Dermatol 2003;149:10951107.

159. Jones GW, Kacinski BM, Wilson LD, et al Total skin electron radiation in the management of mycosis fungoides: Consensus of the European Organization for Research and Treatment of Cancer (EORTC) Cutaneous Lymphoma Project Group. J Am Acad Dermatol 2002;47:364-370.

160. Kempf W, Kettelhack N, Duvic M, Burg G Topical and systemic retinoid therapy for cutaneous T-cell lymphoma. Hematol Oncol Clin North Am 2003;17:1405-1419.

161. Zhang C, Duvic M. Retinoids: Therapeutic applications and mechanisms of action in cutaneous T-cell lymphoma. Dermatol Ther 2003 16:322-330.

162. Nieto-Rementeria N, Perez-Yarza G, Boyano $\mathrm{MD}$, et al. Bexarotene activates the p53/p73 pathway in human cutaneous T-cell lymphoma. Br J Dermatol 2009;160:519-526.

163. Zhang C, Hazarika P, Ni X, et al. Induction of apoptosis by bexarotene in cutaneous T-cell lymphoma cells: Relevance to mechanism of therapeutic action. Clin Cancer Res 2002;8: 1234-1240.

164. Duvic M, Hymes K, Heald P, et al. Bexarotene is effective and safe for treatment of refractory advanced-stage cutaneous T-cell lymphoma: Multinational phase II-III trial results. J Clin Oncol 2001;19:2456-2471.

165. Abbott RA, Whittaker SJ, Morris SL, et al. Bexarotene therapy for mycosis fungoides and Sezary syndrome. Br J Dermatol 2009;160:12991307.

166. Assaf C, Bagot M, Dummer R, et al. Minimizing adverse side-effects of oral bexarotene in cutaneous T-cell lymphoma: An expert opinion. Br J Dermatol 2006;155:261-266.

167. Gniadecki R, Assaf C, Bagot M, et al. The optimal use of bexarotene in cutaneous T-cell lymphoma. Br J Dermatol 2007;157:433-440.
168. Scarisbrick JJ, Morris S, Azurdia R, et al. U.K consensus statement on safe clinical prescribing of bexarotene for patients with cutaneous $\mathrm{T}$ cell lymphoma. Br J Dermatol 2013;168:192200.

169. Huber MA, Kunzi-Rapp K, Staib G, Scharffetter-Kochanek K. Management of refractory early-stage cutaneous T-cell lymphoma (mycosis fungoides) with a combination of oral bexarotene and psoralen plus ultraviolet bath therapy. J Am Acad Dermatol 2004;50:475-476.

170. Schrump DS. Cytotoxicity mediated by histone deacetylase inhibitors in cancer cells: Mechanisms and potential clinical implications. Clin Cancer Res 2009;15:3947-3957.

171. Lemoine $\mathrm{M}$, Younes A. Histone deacetylase inhibitors in the treatment of lymphoma. Discov Med 2010;10:462-470.

172. Gui CY, Ngo L, Xu WS, et al. Histone deacetylase (HDAC) inhibitor activation of p21WAF1 involves changes in promoter-associated proteins, including HDAC1. Proc Natl Acad Sci USA 2004;101:1241-1246.

173. Richon VM, Sandhoff TW, Rifkind RA, Marks PA. Histone deacetylase inhibitor selectively induces p21WAF1 expression and geneassociated histone acetylation. Proc Natl Acad Sci USA 2000;97:10014-10019.

174. Sandor V, Senderowicz A, Mertins S, et al. P21-dependent $\mathrm{g}(1)$ arrest with downregulation of cyclin D1 and upregulation of cyclin E by the histone deacetylase inhibitor FR901228. Br J Cancer 2000;83:817-825.

175. Zhang C, Richon V, Ni X, et al. Selective induction of apoptosis by histone deacetylase inhibitor SAHA in cutaneous T-cell lymphoma cells: Relevance to mechanism of therapeutic action. I Invest Dermatol 2005;125:1045-1052.

176. Shao W, Growney JD, Feng Y, et al. Activity of deacetylase inhibitor panobinostat (LBH589) in cutaneous T-cell lymphoma models: Defining molecular mechanisms of resistance. Int J Cancer 2010;127:2199-2208.

177. Tang Y, Zhao W, Chen Y, et al. Acetylation is indispensable for p53 activation. Cell 2008;133: 612-626.

178. Zhao Y, Lu S, Wu L, et al. Acetylation of p53 at lysine $373 / 382$ by the histone deacetylase inhibitor depsipeptide induces expression of p21(Waf1/Cip1). Mol Cell Biol 2006;26:27822790.

179. Dai Y, Rahmani M, Dent P, Grant S. Blockade of histone deacetylase inhibitor-induced RelA/ p65 acetylation and NF-kappaB activation potentiates apoptosis in leukemia cells through a process mediated by oxidative damage, XIAP downregulation, and c-Jun N-terminal kinase 1 activation. Mol Cell Biol 2005;25:5429-5444.

180. Zhang XD, Gillespie SK, Borrow JM, Hersey P. The histone deacetylase inhibitor suberic bishydroxamate regulates the expression of multiple apoptotic mediators and induces mitochondria-dependent apoptosis of melanoma cells. Mol Cancer Ther 2004;3:425-435.

181. Kim SH, Jeong JW, Park JA, et al. Regulation of the HIF-1alpha stability by histone deacetylases. Oncol Rep 2007;17:647-651.

182. Heider U, Kaiser M, Sterz J, et al. Histone deacetylase inhibitors reduce VEGF production and induce growth suppression and apoptosis in human mantle cell lymphoma. Eur J Haematol 2006;76:42-50.

183. Catley L, Weisberg E, Kiziltepe T, et al. Aggresome induction by proteasome inhibitor bortezomib and alpha-tubulin hyperacetylation by tubulin deacetylase (TDAC) inhibitor LBH589 are synergistic in myeloma cells. Blood 2006; 108:3441-3449.

184. Munshi A, Kurland JF, Nishikawa T, et al. Histone deacetylase inhibitors radiosensitize human melanoma cells by suppressing DNA repair activity. Clin Cancer Res 2005;11:49124922.

185. Rosato RR, Almenara JA, Grant S. The histone deacetylase inhibitor MS-275 promotes differentiation or apoptosis in human leukemia cells 
through a process regulated by generation of reactive oxygen species and induction of p21CIP1/WAF1 1. Cancer Res 2003;63:36373645.

186. Martirosyan A, Leonard S, Shi X, et al. Action of a histone deacetylase inhibitor NSC3852 (5nitroso-8-quinolinol) link reactive oxygen species to cell differentiation and apoptosis in MCF-7 human mammary tumor cells. J Pharmacol Exp Ther 2006;317:546-552.

187. Weiser TS, Ohnmacht GA, Guo ZS, et al. Induction of MAGE-3 expression in lung and esophageal cancer cells. Ann Thorac Surg 2001;71:295-301; discussion 301-292.

188. Tiffon C, Adams J, van der Fits L, et al. The histone deacetylase inhibitors vorinostat and romidepsin downmodulate IL-10 expression in cutaneous T-cell lymphoma cells. Br J Pharmacol 2011;162:1590-1602.

189. Gloghini A, Buglio D, Khaskhely NM, et al. Expression of histone deacetylases in lymphoma: Implication for the development of selective inhibitors. Br J Haematol 2009;147:515-525.

190. Prince HM, Bishton MJ, Harrison SJ. Clinical studies of histone deacetylase inhibitors. Clin Cancer Res 2009;15:3958-3969.

191. Duvic M, Talpur R, Ni X, et al. Phase 2 trial of oral vorinostat (suberoylanilide hydroxamic acid, SAHA) for refractory cutaneous T-cell lymphoma (CTCL). Blood 2007;109:31-39.

192. Olsen EA, Kim YH, Kuzel TM, et al. Phase IIb multicenter trial of vorinostat in patients with persistent, progressive, or treatment refractory cutaneous T-cell lymphoma. J Clin Oncol 2007;25:3109-3115.

193. Kim E, Rook A, Kim Y, et al. Romidepsin activity in all three disease compartment (skin, blood, lymph nodes) in patients with cutaneous T-cell lymphoma (CTCL). J Clin Oncol 2010;28:abstract 8047

194. Duvic M, Olsen EA, Breneman D, et al. Evaluation of the long-term tolerability and clinical benefit of vorinostat in patients with advanced cutaneous T-cell lymphoma. Clin Lymphoma Myeloma 2009;9:412-416.

195. Whittaker SJ, Demierre MF, Kim EJ, et al Final results from a multicenter, international, pivotal study of romidepsin in refractory cutaneous T-cell lymphoma. J Clin Oncol 2010;28: 4485-4491.

196. Piekarz RL, Frye R, Turner $\mathrm{M}$, et al. Phase II multi-institutional trial of the histone deacetylase inhibitor romidepsin as monotherapy for patients with cutaneous T-cell lymphoma. J Clin Oncol 2009;27:5410-5417.

197. Piekarz RL, Frye AR, Wright JJ, et al. Cardiac studies in patients treated with depsipeptide FK228, in a phase II trial for T-cell lymphoma. Clin Cancer Res 2006;12:3762-3773.

198. Ellis L, Pan Y, Smyth GK, et al. Histone deacetylase inhibitor panobinostat induces clinical responses with associated alterations in gene expression profiles in cutaneous T-cell lymphoma. Clin Cancer Res 2008;14:4500-4510.

199. Pohlman B, Advani RH, Duvic M, et al. Final results of a phase II trial of Belinostat (PXD101) in patients with recurrent or refractory peripheral or cutaneous T-cell lymphoma. Blood 2009;114:abstract 920.

200. Fantin VR, Loboda A, Paweletz CP, et al. Constitutive activation of signal transducers and activators of transcription predicts vorinostat resistance in cutaneous T-cell lymphoma. Cancer Res 2008:68:3785-3794.

201. Robey RW, Zhan Z, Piekarz RL, et al Increased MDR1 expression in normal and malignant peripheral blood mononuclear cells obtained from patients receiving depsipeptide (FR901228, FK228, NSC630176). Clin Cancer Res 2006;12:1547-1555.

202. Karpova MB, Gunz D, Okoniewski MJ, et al. Transcriptome adaptation caused by vorinostat/bexarotene combination therapy in advanced cutaneous T-cell lymphoma. J Clin Oncol 2010;28:abstract 8050.

203. Khan O, Fotheringham S, Wood V, et al HR23B is a biomarker for tumor sensitivity to
HDAC inhibitor-based therapy. Proc Nat Acad Sci USA 2010;107:6532-6537.

204. Chakraborty AR, Robey RW, Luchenko VL, et al. MAPK pathway activation leads to Bim loss and histone deacetylase inhibitor resistance: Rationale to combine romidepsin with an MEK inhibitor. Blood 2013;121:4115-4125

205. Heider U, Rademacher J, Lamottke B, et al. Synergistic interaction of the histone deacetylase inhibitor SAHA with the proteasome inhibitor bortezomib in cutaneous $\mathrm{T}$ cell lym phoma. Eur J Haematol 2009;82:440-449.

206. Dummer R, Hymes K, Sterry W, et al. Vorinostat in combination with bexarotene in advanced cutaneous T-cell lymphoma: A phase I study. J Clin Oncol 2009;27:abstract 8572.

207. Olsen EA, Rosen ST, Vollmer RT, et al. Interferon alfa-2a in the treatment of cutaneous $\mathrm{T}$ cell lymphoma. J Am Acad Dermatol 1989;20: 395-407.

208. Sun WH, Pabon C, Alsayed $\mathrm{Y}$, et al. Interferon-alpha resistance in a cutaneous $\mathrm{T}$-cell lymphoma cell line is associated with lack of STAT1 expression. Blood 1998;91:570-576.

209. Bunn PA Jr., Foon KA, Ihde DC, et al Recombinant leukocyte A interferon: An active agent in advanced cutaneous T-cell lymphomas. Ann Intern Med 1984;101:484-487.

210. Jumbou O, N'Guyen JM, Tessier MH, et al. Long-term follow-up in 51 patients with mycosis fungoides and Sezary syndrome treated by interferon-alfa. Br J Dermatol 1999;140:427-431.

211. Olsen EA, Bunn PA. Interferon in the treatment of cutaneous T-cell lymphoma. Hemato Oncol Clin North Am 1995:9:1089-1107.

212. Kuzel TM, Gilyon K, Springer E, et al. Interferon alfa-2a combined with phototherapy in the treatment of cutaneous T-cell lymphoma. J Natl Cancer Inst 1990;82:203-207.

213. Straus DJ, Duvic M, Kuzel T, et al. Results of phase II trial of oral bexarotene (Targretin) combined with interferon alfa-2b (Intron-A) for patients with cutaneous T-cell lymphoma. Cancer 2007;109:1799-1803.

214. Dippel E, Schrag H, Goerdt S, Orfanos CE Extracorporeal photopheresis and interferon alpha in advanced cutaneous T-cell lymphoma. Lancet 1997;350:32-33.

215. Foss FM, Ihde DC, Breneman DL, et al. Phase II study of pentostatin and intermittent highdose recombinant interferon alfa-2a in advanced mycosis fungoides/Sezary syndrome. J Clin Oncol 1992;10:1907-1913.

216. Fritz TM, Kleinhans M, Nestle FO, et al. Com bination treatment with extracorporeal photopheresis, interferon alfa and interleukin-2 in patient with the Sezary syndrome. Br J Dermatol 1999;140:1144-1147.

217. Zachariae H, Thestrup-Pedersen K. Interferon alpha and etretinate combination treatment of cutaneous T-cell lymphoma. J Invest Dermato 1990;95:206S-208S.

218. Papa G, Tura S, Mandelli F, et al. Is interferon alpha in cutaneous T-cell lymphoma a treat ment of choice? Br J Haematol 1991;79 Suppl $1: 48-51$

219. Rupoli S, Barulli S, Guiducci B, et al. Low dose interferon-alpha2b combined with PUVA is an effective treatment of early stage mycosis fun goides: Results of a multicenter study. Cutaneous-T Cell Lymphoma Multicenter Study Group. Haematologica 1999;84:809-813.

220. Kuzel TM, Roenigk HH Jr., Samuelson E, et al. Effectiveness of interferon alfa-2a combined with phototherapy for mycosis fungoides and the Sezary syndrome. J Clin Oncol 1995;13 257-263.

221. Roenigk HH Jr., Kuzel TM, Skoutelis AP, et al. Photochemotherapy alone or combined with interferon alpha-2a in the treatment of cutaneous T-cell lymphoma. J Invest Dermatol 1990; 95:198S-205S.

222. Chiarion-Sileni V, Bononi A, Fornasa CV et al. Phase II trial of interferon-alpha-2a plus psolaren with ultraviolet light $\mathrm{A}$ in patient with cutaneous T-cell lymphoma. Cancer 2002; 95:569-575.
223. Foss FM, Ihde DC, Linnoila IR, et al. Phase II trial of fludarabine phosphate and interferon alfa-2a in advanced mycosis fungoides/Sezary syndrome. J Clin Oncol 1994;12:2051-2059.

224. Suchin KR, Cucchiara AJ, Gottleib SL, et al Treatment of cutaneous T-cell lymphoma with combined immunomodulatory therapy: A 14year experience at a single institution. Arch Dermatol 2002;138:1054-1060.

225. Bladon J, Taylor PC. Lymphocytes treated by extracorporeal photopheresis demonstrate a drop in the Bcl-2/Bax ratio: A possible mechanism involved in extracorporeal-photopheresisinduced apoptosis. Dermatology 2002;204:104107

226. Bladon J, Taylor PC. Extracorporeal photopheresis: A focus on apoptosis and cytokines. Dermatol Sci 2006;43:85-94.

227. Osella-Abate S, Zaccagna A, Savoia P, et al. Expression of apoptosis markers on peripheral blood lymphocytes from patients with cutaneous T-cell lymphoma during extracorporeal photochemotherapy. J Am Acad Dermatol 2001;44:40-47.

228. Berger C, Hoffmann K, Vasquez JG, et al. Rapid generation of maturationally synchronized human dendritic cells: Contribution to the clinical efficacy of extracorporeal photochemotherapy. Blood 2010;116:4838-4847.

229. Berger $\mathrm{CL}, \mathrm{Xu} \mathrm{AL}$, Hanlon $\mathrm{D}$, et al. Induction of human tumor-loaded dendritic cells. Int Cancer 2001;91:438-447.

230. Girardi M, Berger CL, Wilson LD, et al. Transimmunization for cutaneous $\mathrm{T}$ cell lymphoma: A Phase I study. Leuk Lymphoma 2006;47: 1495-1503.

231. Edelson R, Berger C, Gasparro F, et al. Treatment of cutaneous T-cell lymphoma by extracorporeal photochemotherapy. Preliminary results. N Engl J Med 1987;316:297-303.

232. Knobler R, Jantschitsch C. Extracorporeal photochemoimmunotherapy in cutaneous T-cell lymphoma. Transfus Apher Sci 2003;28:81-89.

233. Zic JA. The treatment of cutaneous T-cell lymphoma with photopheresis. Dermatol Ther 2003;16:337-346.

234. Quaglino P, Knobler R, Fierro MT, et al Extracorporeal photopheresis for the treatment of erythrodermic cutaneous T-cell lymphoma: A single center clinical experience with longterm follow-up data and a brief overview of the literature. Int J Dermatol 2013;52:13081318.

235. Knobler R, Berlin G, Calzavara-Pinton P, et al Guidelines on the use of extracorporeal photopheresis. J Eur Acad Dermatol Venereol 2014 28 Suppl 1:1-37.

236. Gottlieb SL, Wolfe JT, Fox FE, et al. Treatment of cutaneous T-cell lymphoma with extracorporeal photopheresis monotherapy and in combination with recombinant interferon alfa: A 10-year experience at a single institution. J Am Acad Dermatol 1996;35:946-957.

237. Heald P, Rook A, Perez M, et al. Treatment of erythrodermic cutaneous T-cell lymphoma with extracorporeal photochemotherapy. J Am Acad Dermatol 1992;27:427-433.

238. Zic JA, Stricklin GP, Greer JP, et al. Long-term follow-up of patients with cutaneous T-cell lymphoma treated with extracorporeal photochemotherapy. J Am Acad Dermatol 1996;35: 935-945.

239. Wilson LD, Jones GW, Kim D, et al. Experience with total skin electron beam therapy in combination with extracorporeal photopheresis in the management of patients with erythrodermic (T4) mycosis fungoides. I Am Acad Dermatol 2000;43:54-60.

240. Wilson LD, Licata AL, Braverman IM, et al Systemic chemotherapy and extracorporeal photochemotherapy for T3 and T4 cutaneous T-cell lymphoma patients who have achieved a complete response to total skin electron beam therapy. Int J Radiat Oncol Biol Phys 1995;32: 987-995.

241. Tsirigotis P, Pappa V, Papageorgiou S, et al. Extracorporeal photopheresis in combination 
with bexarotene in the treatment of mycosis fungoides and Sezary syndrome. Br J Dermatol 2007;156:1379-1381.

242. Ginaldi L, De Martinis M, Matutes E, et al. Levels of expression of CD52 in normal and leukemic $\mathrm{B}$ and $\mathrm{T}$ cells: Correlation with in vivo therapeutic responses to Campath- $1 \mathrm{H}$. Leuk Res 1998;22:185-191.

243. Lundin J, Hagberg H, Repp R, et al. Phase 2 study of alemtuzumab (anti-CD52 monoclonal antibody) in patients with advanced mycosis fungoides/Sezary syndrome. Blood 2003;101: 4267-4272.

244. Bernengo MG, Quaglino P, Comessatti A, et al. Low-dose intermittent alemtuzumab in the treatment of Sezary syndrome: Clinical and immunologic findings in 14 patients. Haematologica 2007;92:784-794.

245. Fisher DC, Tawa M, Walsh M, et al. Low-dose alemtuzumab is uniquely effective in refractory leukemic cutaneous T-cell lymphoma (LCTCL). Blood 2009;114:abstract 3748.

246. Thursky KA, Worth LJ, Seymour JF, et al Spectrum of infection, risk and recommendations for prophylaxis and screening among patients with lymphoproliferative disorders treated with alemtuzumab* ${ }^{*} \mathrm{Br}$ J Haematol 2006;132:3-12.

247. Enblad G, Hagberg H, Erlanson M, et al. A pilot study of alemtuzumab (anti-CD52 monoclonal antibody) therapy for patients with relapsed or chemotherapy-refractory peripheral T-cell lymphomas. Blood 2004;103:2920-2924.

248. Gautschi O, Blumenthal N, Streit M, et al. Successful treatment of chemotherapy-refractory Sezary syndrome with alemtuzumab (Campath-1H). Eur J Haematol 2004;72:61-63.

249. Kennedy GA, Seymour JF, Wolf M, et al. Treatment of patients with advanced mycosis fungoides and Sezary syndrome with alemtuzumab. Eur J Haematol 2003;71:250-256.

250. O’Mahony D, Morris JC, Moses L, et al. Phase I Trial of Siplizumab in CD2-Positive Lymphoproliferative Disease. Blood 2005;106:abstract 3353.

251. Kim YH, Duvic M, Obitz E, et al. Clinical efficacy of zanolimumab (HuMax-CD4): Two phase 2 studies in refractory cutaneous T-cell lymphoma. Blood 2007;109:4655-4662.

252. Kreitman RJ, Wilson WH, White JD, et al. Phase I trial of recombinant immunotoxin anti-Tac(Fv)-PE38 (LMB-2) in patients with hematologic malignancies. J Clin Oncol 2000; 18:1622-1636

253. Suzuki R. Dosing of a phase I study of KW0761, an anti-CCR4 antibody, for adult T-cell leukemia-lymphoma and peripheral T-cell lymphoma. J Clin Oncol 2010;28:e404-405; author reply e406.

254. Yamamoto K, Utsunomiya A, Tobinai K, et al. Phase I study of KW-0761, a defucosylated humanized anti-CCR4 antibody, in relapsed patients with adult T-cell leukemia-lymphoma and peripheral T-cell lymphoma. J Clin Oncol 2010;28:1591-1598.

255. Duvic M, Pinter-Brown L, Foss F, et al. Results of a phase 1/2 Study for KW-0761, a Monoclonal Antibody Directed Against CC Chemokine Receptor Type 4 (CCR4), In CTCL Patients. Blood 2010;116:Abstract 285.

256. Ogura M, Ishida T, Hatake K, et al. Multicenter Phase II Study of Mogamulizumab (KW 0761), a Defucosylated Anti-CC Chemokine Receptor 4 Antibody, in Patients With Relapsed Peripheral T-Cell Lymphoma and Cutaneous T-Cell Lymphoma. J Clin Oncol 2014;32:1157-1163.

257. Krathen M, Sundram M, Bashey S, et al. Brentuximab vedotin demonstrates significant clinical activity in relapsed or refractory mycosis fungoides with variable CD30 expression. Blood (ASH Annual Meeting Abstracts) 2012; 120

258. Whittaker SJ, Foss FM. Efficacy and tolerability of currently available therapies for the mycosis fungoides and Sezary syndrome variants of cutaneous T-cell lymphoma. Cancer Treat Rev 2007;33:146-160.

259. Akpek G, Koh HK, Bogen S, et al. Chemotherapy with etoposide, vincristine, doxorubicin, bolus cyclophosphamide, and oral prednisone in patients with refractory cutaneous T-cell lymphoma. Cancer 1999;86:1368-1376.

260. Molin L, Thomsen K, Volden G, et al. Combination chemotherapy in the tumour stage of mycosis fungoides with cyclophosphamide, vincristine, vp-16, adriamycin and prednisolone (cop, chop, cavop): A report from the Scandinavian mycosis fungoides study group. Acta Derm Venereol 1980;60:542-544

261. Duvic M, Lemak NA, Redman JR, et al. Combined modality therapy for cutaneous T-cell lymphoma. J Am Acad Dermatol 1996;34: 1022-1029.

262. Zackheim HS, Epstein EH Jr. Low-dose methotrexate for the Sezary syndrome. J Am Acad Dermatol 1989;21:757-762.

263. Zackheim HS, Kashani-Sabet M, Hwang ST. Low-dose methotrexate to treat erythrodermic cutaneous T-cell lymphoma: Results in twentynine patients. J Am Acad Dermatol 1996;34. 626-631.

264. Zackheim HS, Kashani-Sabet M, McMillan A. Low-dose methotrexate to treat mycosis fungoides: A retrospective study in 69 patients. J Am Acad Dermatol 2003;49:873-878.

265. Vonderheid EC, Sajjadian A, Kadin ME. Methotrexate is effective therapy for lymphomatoid papulosis and other primary cutaneous CD30 positive lymphoproliferative disorders. J Am Acad Dermatol 1996:34:470-481.

266. Zinzani PL, Magagnoli M, Bendandi M, et al. Therapy with gemcitabine in pretreated periph eral T-cell lymphoma patients. Ann Oncol 1998;9:1351-1353.

267. Zinzani PL, Baliva G, Magagnoli $M$, et al Gemcitabine treatment in pretreated cutaneous T-cell lymphoma: Experience in 44 patients. J Clin Oncol 2000;18:2603-2606.

268. Marchi E, Alinari L, Tani M, et al. Gemcitabine as frontline treatment for cutaneous T-cell lymphoma: Phase II study of 32 patients. Cancer 2005;104:2437-2441.

269. Duvic M, Talpur R, Wen S, et al. Phase II evaluation of gemcitabine monotherapy for cutaneous T-cell lymphoma. Clin Lymphoma Myeloma 2006;7:51-58.

270. Zinzani PL, Venturini F, Stefoni V, et al. Gemcitabine as single agent in pretreated T-cell lymphoma patients: Evaluation of the longterm outcome. Ann Oncol 2010;21:860-863.

271. Wollina U, Graefe T, Karte K. Treatment of relapsing or recalcitrant cutaneous T-cell lymphoma with pegylated liposomal doxorubicin. J Am Acad Dermatol 2000;42:40-46.

272. Wollina U, Dummer R, Brockmeyer NH, et al Multicenter study of pegylated liposomal doxorubicin in patients with cutaneous T-cell lymphoma. Cancer 2003;98:993-1001.

273. Pulini S, Rupoli S, Goteri G, et al. Pegylated liposomal doxorubicin in the treatment of primary cutaneous T-cell lymphomas. Haematologica 2007;92:686-689.

274. Quereux G, Marques S, Nguyen JM, et al. Prospective multicenter study of pegylated liposomal doxorubicin treatment in patients with advanced or refractory mycosis fungoides or Sezary syndrome. Arch Dermatol 2008;144 727-733.

275. Cummings FJ, Kim K, Neiman RS, et al. Phase II trial of pentostatin in refractory lymphomas and cutaneous T-cell disease. J Clin Oncol 1991;9:565-571.

276. Dearden C, Matutes E, Catovsky D. Deoxycoformycin in the treatment of mature T-cell leukaemias. Br J Cancer 1991;64:903-906.

277. Mercieca J, Matutes E, Dearden C, et al. The role of pentostatin in the treatment of $\mathrm{T}$-cell malignancies: Analysis of response rate in 145 patients according to disease subtype. J Clin Oncol 1994;12:2588-2593.
278. Greiner D, Olsen EA, Petroni G. Pentostatin (2'-deoxycoformycin) in the treatment of cutaneous T-cell lymphoma. J Am Acad Dermatol 1997;36:950-955.

279. Ho AD, Suciu S, Stryckmans P, et al. Pentostatin in T-cell malignancies-a phase II trial of the EORTC. Leukemia Cooperative Group. Ann Oncol 1999;10:1493-1498.

280. Kurzrock R, Pilat S, Duvic M. Pentostatin therapy of T-cell lymphomas with cutaneous manifestations. J Clin Oncol 1999;17:3117-3121.

281. Tsimberidou AM, Giles F, Duvic M, et al Phase II study of pentostatin in advanced $\mathrm{T}$ cell lymphoid malignancies: Update of an M.D. Anderson Cancer Center series. Cancer 2004; 100:342-349.

282. Jidar K, Ingen-Housz-Oro S, Beylot-Barry M, et al. Gemcitabine treatment in cutaneous $\mathrm{T}$ cell lymphoma: A multicentre study of 23 cases. Br J Dermatol 2009;161:660-663.

283. O'Connor OA, Hamlin PA, Portlock C, et al Pralatrexate, a novel class of antifol with high affinity for the reduced folate carrier-type 1 , produces marked complete and durable remissions in a diversity of chemotherapy refractory cases of T-cell lymphoma. Br J Haematol 2007; 139:425-428.

284. Serova M, Bieche I, Sablin MP, et al. Single agent and combination studies of pralatrexate and molecular correlates of sensitivity. $\mathrm{Br} \mathrm{J}$ Cancer 2011;104:272-280.

285. Zain J, O'Connor O. Pralatrexate: Basic understanding and clinical development. Expert Opin Pharmacother 2010;11:1705-1714.

286. O'Connor OA, Pro B, Pinter-Brown L, et al. Pralatrexate in patients with relapsed or refractory peripheral T-cell lymphoma: Results From the Pivotal PROPEL Study. J Clin Oncol 2011; 29:1182-1189.

287. Foss F, Horwitz S, Pinter-Brown L, et al. Pralatrexate is an effective treatment for heavily pretreated patients with relapsed/refractory transformed mycosis fungoides (tMF). Blood 2010;116 Abstract 1762.

288. Horwitz S, Kim YH, Foss F, et al. Identification of an active, well-tolerated dose of pralatrexate in patients with relapsed or refractory cutaneous T-cell lymphoma (CTCL): Final results of a multicenter dose-finding study. Blood 2010; 116:Abstract 2800

289. Rueda A, Casanova M, Quero C, Medina-Perez A. Pralatrexate, a new hope for aggressive Tcell lymphomas? Clin Transl Oncol 2009;11: 215-220.

290. Zinzani PL, Musuraca G, Tani M, et al. Phase II trial of proteasome inhibitor bortezomib in patients with relapsed or refractory cutaneous T-cell lymphoma. J Clin Oncol 2007;25:42934297.

291. Wu PA, Kim YH, Lavori PW, et al. A metaanalysis of patients receiving allogeneic or autologous hematopoietic stem cell transplant in mycosis fungoides and Sezary syndrome. Biol Blood Marrow Transplant 2009;15:982990.

292. Duarte RF, Schmitz N, Servitje O, Sureda A. Haematopoietic stem cell transplantation for patients with primary cutaneous T-cell lymphoma. Bone Marrow Transplant 2008;41:597604.

293. Duarte RF, Canals C, Onida F, et al. Allogeneic hematopoietic cell transplantation for patients with mycosis fungoides and Sezary syndrome: A retrospective analysis of the Lymphoma Working Party of the European Group for Blood and Marrow Transplantation. J Clin Oncol 2010;28:4492-4499.

294. Schlaak M, Theurich S, Pickenhain J, et al Allogeneic stem cell transplantation for advanced primary cutaneous T-cell lymphoma: A systematic review. Crit Rev Oncol Hematol 2013;85:21-31. 